\title{
Adsorption of azo dyes on polymer materials
}

\author{
Vesna V. Panić ${ }^{1}$, Sanja I. Šešlija ${ }^{1}$, Aleksandra R. Nešić ${ }^{2}$, Sava J. Veličković ${ }^{3}$ \\ ${ }^{1}$ Innovation Center of the Faculty of Technology and Metallurgy, University of Belgrade, 11000 Belgrade, Serbia \\ ${ }^{2}$ Vinca Institute of Nuclear Science, University of Belgrade, 11000, Belgrade, Serbia \\ ${ }^{3}$ Faculty of Technology and Metallurgy, University of Belgrade, 11000, Belgrade, Serbia
}

\begin{abstract}
The use of polymeric adsorbents for the removal of azo dyes from solution has been reviewed. Adsorption techniques are widely used to remove certain classes of pollutants from waters, especially those which are not easily biodegradable. The removal of azo dyes as pollutants from wastewaters of textile, paper, printing, leather, pharmaceutical and other industries has been addressed by the researchers. The wider use of already available adsorbents is restricted due to their high costs which lead to investigation and development of new materials that can be cheaper, eficient and easy regenerated. The aim of this article is to present to the readers the widespread investigations in recent years of synthetic and natural polymers as adsorbents and potential replacement of conventional adsorbents. This review presents only the data obtained using raw, hydrogel, grafted and crosslinked forms of synthetic and nature based polymers, and the discussion is limited to these polymer-based materials and their adsorption properties.
\end{abstract}

Keywords: adsorption, azo dyes, synthetic polymers, hydrogels, natural polymers.

\section{Polymers}

REVIEW PAPER

UDC 66.081.3:667.281:678.7/.8

Hem. Ind. 67 (6) 881-900 (2013)

doi: 10.2298/HEMIND121203020P

Available online at the Journal website: http://www.ache.org.rs/HI/

The intensive development of industrial production throughout the world has been followed by ever increasing formation of wastewaters, demanding improvement of the existing, and introduction of new processes for their treatment. The presence of dyes in wastewaters from industrial effluents and water supplies and their removal has received much attention in recent years due to the fact that many of them exhibit toxicity. Pollution by dyes is a serious threat to the aquatic ecosystem, which affects the quality of life and human health as well. Among the unwanted properties of dyes, resistance to natural degradation, allergenicity, carcinogenity, and mutagenicity are all significant. They can also cause severe damage to human beings, such as dysfunction of kidneys, reproductive system, liver, brain and central nervous system [1-4]. Even in very small quantities, dyes can be very toxic and lead to changes in salinity and visible coloration of the water, reducing sunlight penetration and thus hindering the process of photosynthesis [5-7]. Very strict laws regarding elimination of dyes from wastewaters before their discharge into water streams, together with the variety and minuscule concentrations of dye molecules make their satisfactory level of removing very difficult, requiring development of various technologies for dye elimination.

Correspondence: A.R. Nešić, Vinča Institute of Nuclear Science, University of Belgrade, 11000, Belgrade, Serbia.

E-mail: anesic@vin.bg.ac.rs

Paper received: 3 December, 2012

Paper accepted: 12 February, 2013
Therefore, decolorization of dyes is another important aspect of wastewater treatment before discharge into environment.

In this review, the use of polymer materials, both synthetic and natural by origin, for removal of azo dyes from aqueous solutions is presented. Polymeric adsorbents show increasing advantages over conventional adsorbents because of their simple processing, relatively easy regeneration and the possibility to shape them into most suitable form (e.g., sheets, beads, membranes). This review presents only the data obtained using raw, hydrogel, grafted and crosslinked forms of synthetic and naturally based polymers, and the discussion will be limited to these polymer-based materials and their adsorption properties. The effects of various parameters such as polymer characteristics and the activation conditions on biosorption are presented and discussed.

\section{CLASSIFICATION OF DYES}

Dyes exhibit considerable structural diversity, and can be classified by their chemical structure or their application to the fiber type. Dyes must carry one or more functionalities giving the dye color, called chromophores, as well as an electron withdrawing or donating substituents that cause or intensify the color of the chromophores, called auxochrom. The chromophore group can be a base for dye classification. The most important chromophores are azo $(-\mathrm{N}=\mathrm{N}-)$, carbonyl $(-\mathrm{C}=\mathrm{O})$, methine $(-\mathrm{CH}=)$, nitro $\left(-\mathrm{NO}_{2}\right)$ and quinoid groups. The most important auxochromes are amine ($\left.\mathrm{NH}_{3}\right)$, carboxyl $(-\mathrm{COOH})$, sulfonate $\left(-\mathrm{SO}_{3} \mathrm{H}\right)$ and hydro- 
$\mathrm{xyl}(-\mathrm{OH})$ groups. Dyes may also be classified according to their solubility: soluble dyes like acid, basic, metal complex, direct, mordant and reactive dyes or insoluble dyes including sulfur, azoic, vat and disperse dyes.

Almost $10^{9} \mathrm{~kg}$ of dyes are produced annually in the world, of which azo dyes represent about $70 \%$ by weight [8]. Because such large quantities of azodyes are being produced and used daily by leather tanning, textile, paper production, food industry, etc. and since they are known to transform to carcinogenic aromatic amines in the environment, their incorrect disposal is a major environmental concern and can affect human and animal health [9]. As removal of azo dyes is of a particular interest for this revew, some typical azo dyes are represented in Figure 1.
As can be seen from the presented structures, azo dyes possess a lot of reactive groups that enables good bonding to the substrate (for example: silk, wool, cotton, nylon fibers, etc.) through formation of covalent and physical bonds with- $\mathrm{OH},-\mathrm{NH}$, or $-\mathrm{SH}$ groups in its structure.

\section{COMMON WATER-TREATMENT METHODS FOR REMOVAL OF DYES}

A vast array of processes are currently in use for removal of dyes from wastewaters such as: biological treatments [11-13], flocculation and coagulation [14-16], advanced oxidation [17-19], adsorption processes [20-23], etc. Table 1 presents the most widely
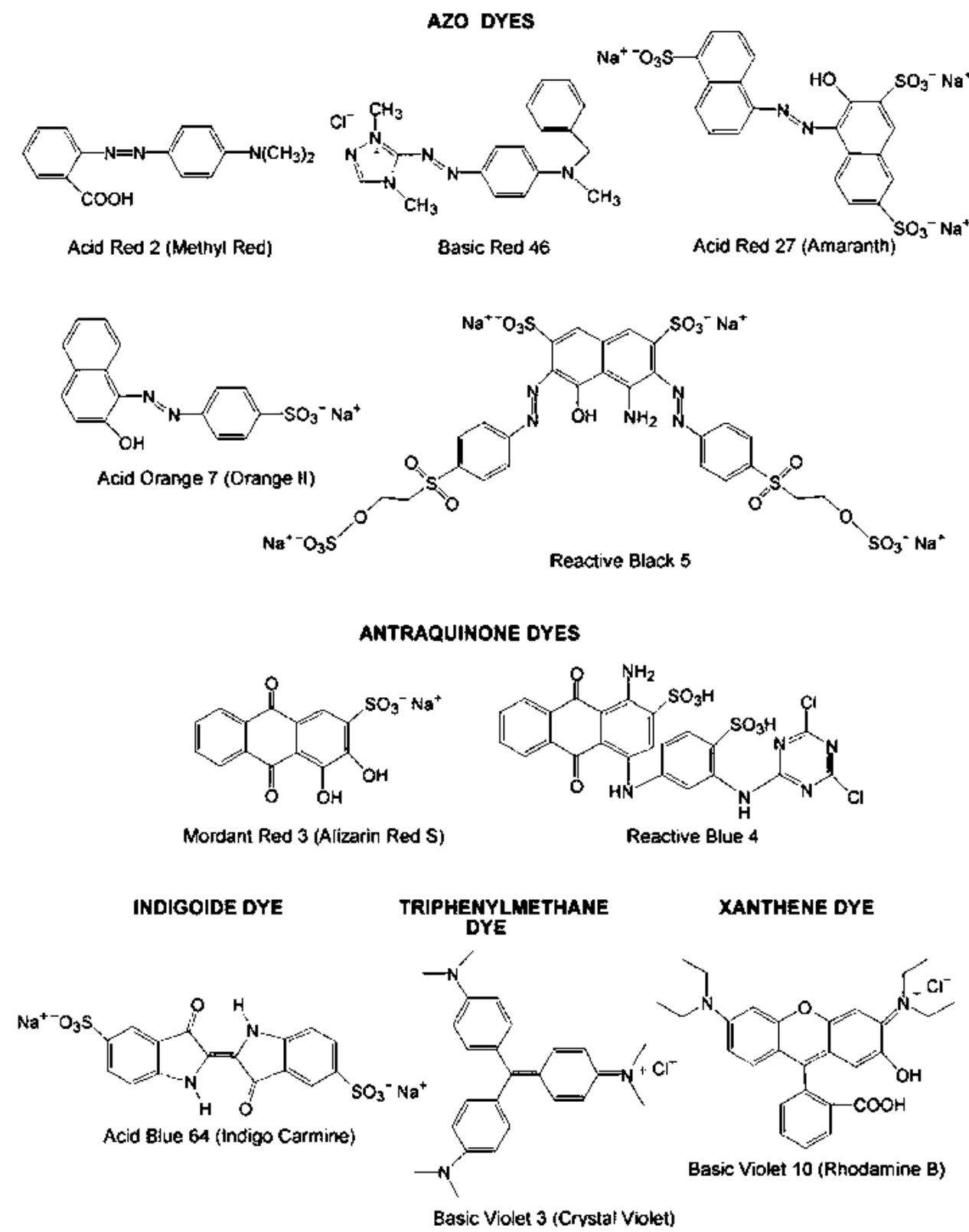

Figure 1. Chemical structures of typical synthetic azo dyes. 
Table 1. Advantages and drawbacks of commonly used methods for removal of pollutants from wastewaters

\begin{tabular}{|c|c|c|}
\hline Methods & Advantages & Drawbacks \\
\hline Ozonation & No sludge production & Short half-life of ozone (20 min) \\
\hline Oxidative process $\left(\mathrm{H}_{2} \mathrm{O}_{2}\right)$ & Simplicity of application & $\mathrm{H}_{2} \mathrm{O}_{2}$ should be first activated \\
\hline Fenton reagents, $\mathrm{H}_{2} \mathrm{O}_{2}+\mathrm{Fe}$ (II) salt & $\begin{array}{l}\text { High efficiency of water-soluble and non water- } \\
\text { soluble pollutants }\end{array}$ & Big sludge production \\
\hline Photochemical degradation $\left(\mathrm{UV} / \mathrm{H}_{2} \mathrm{O}_{2}\right)$ & No sludge production & Formation of side products, high cost \\
\hline Adsorption & $\begin{array}{l}\text { High efficiency for removal of different types of } \\
\text { dyes and metal ions }\end{array}$ & Regeneration of adsorbents \\
\hline Ionic exchange (resin) & Regeneration-no adsorbent loss & Low adsorption capacity \\
\hline Electrokinetic coagulation & Low cost & High sludge production \\
\hline Irradiation & Effective oxidation at lab scale & High cost, requires a lot of dissolved $\mathrm{O}_{2}$ \\
\hline Biological process & Ecological feasible & $\begin{array}{c}\text { Slow process, low range of operated } \\
\text { temperature }\end{array}$ \\
\hline Coagulation/flocculation & Low cost & $\begin{array}{l}\text { Heavy chemical consumption, high sludge } \\
\text { production }\end{array}$ \\
\hline
\end{tabular}

used methods for removal of dyes from wastewater, along with their advantages and drawbacks.

Despite the large number of methods, the application of most of them is often limited by costs of the process itself (especially when applied in small plants), inefficiency and the need to remove the sludge after treatment [24]. Another limiting factor is the formation of toxic degradation products that may happen in some cases. Adsorption processes are becoming increasingly popular as a way of treatment not only of colored effluents but of various other kinds of wastewaters as well, because of their economical feasibility, simplicity and a high level of efficiency.

\section{ADSORPTION OF DYES ON POLYMER MATERIALS}

Interest in finding adequate, cost-effective adsorbents with sufficient adsorption capacity, adsorption rate and mechanical properties has increased extensively in recent times. Different types of activated carbon are generally used, and therefore these are the most often investigated sorbents for removal of dyes from wastewaters [25-27]. However, their use is limited because they are expensive sorbents with highcost regeneration, and taking into account the cost of treatment of polluted water is increasingly important.

Often suggested alternatives are natural materials $[28,29]$ that are renewable or plentiful, usually used without or with minimal pretreatment; waste and by-products in various industries, agriculture and households [30] whose use reduces the cost of sorption process and contributes to preservation of the environment, and low-cost synthetic materials, such as polymer materials, with tailor-made properties for removal of particular pollutant and /or suitable to be applied in specific conditions [31,32].
Polymeric adsorbents show increasing advantages over conventional adsorbents (activated carbon, ion-exchangers, etc.) because of their simple processing, the possibility to be tailor-made and that their adsorption is generally a reversible process, i.e. the adsorbed dyes from waste streams could be effectively desorbed under mild conditions for resource recovery or further treatment. The desorption reagents required depend mainly on the properties of the adsorbed dye, the typical ones being inorganic acids (e.g., $\mathrm{HCl}$ or $\mathrm{H}_{2} \mathrm{SO}_{4}$ ), alkaline $\left(\mathrm{NaOH}\right.$ or $\mathrm{Na}_{2} \mathrm{CO}_{3}$ ), or organic solvents (methanol, alcohol or acetone) [33-36].

The separation of dyes is mainly achieved from aqueous solutions, where the driving force for the adsorption is very strong and enables a fast process.

Various molecular and especially functional groups along polymer chains can form different interactions with dye molecules. Depending on the dominant type of interactions between dye and adsorbent, the adsorption can be physical or chemical by nature. If the adsorbate (dye) molecules are attracted by weak van der Waals forces towards the adsorbent molecules, the adsorption is known as physical adsorption or physisorption, whereas when the dye molecules are bound to the surface of adsorbent by chemical bonds, the adsorption is known as chemical adsorption or chemisorption. Some features which are useful in recognizing physisorption and chemisorption are presented in Table 2.

\section{Adsorption of azo dyes on synthetic polymer materials}

In recent years, functional polymers have been increasingly tested as a potential alternative to traditional adsorbents due to their vast surface area, perfect mechanical rigidity, adjustable surface chemistry and feasible regeneration under mild conditions [37]. Synthetic polymers have few more significant advantages 
Table 2. General characteristics of physisorption and chemisorption

\begin{tabular}{|c|c|}
\hline Physisoprtion & Chemisoprtion \\
\hline $\begin{array}{l}\text { Low heat of adsorption ( }<2 \text { or } 3 \text { times the latent heat of } \\
\text { evaporation) }\end{array}$ & $\begin{array}{l}\text { High heat of adsorption ( }>2 \text { or } 3 \text { times the latent heat of } \\
\text { evaporation) }\end{array}$ \\
\hline Relatively low temperature, always & High temperatures \\
\hline \multicolumn{2}{|l|}{ under the critical temperature of the adsorbate } \\
\hline Non-specific & $\begin{array}{l}\text { Type of interaction: strong; covalent bond between adsorbate } \\
\text { and surface }\end{array}$ \\
\hline Adsorption takes place in monolayer or multilayer & Adsorption takes place only in a monolayer \\
\hline Low activation energy & High activation energy \\
\hline Rapid, non-activated, reversible & Reversible only at high temperature \\
\hline No dissociation of adsorbed species & Increase in electron density in the adsorbent-adsorbate interface \\
\hline
\end{tabular}

over other adsorbent materials; for example, they can be readily manufactured in a wide range of physicochemical properties (form, size, size distribution, porosity, hydrophobicity, etc.) and they are tunable by inserting various ligands into the structure in order to produce specific sorbents [38-40]. A wide range of polymerization techniques (conventional free-radical polymerization, $\gamma$-radiation polymerization, ring opening metathesis polymerization (ROMP), atom transfer radical polymerization (ATRP), single-electron transfer living radical polymerization (SET-LRP), reversible addition fragmentation chain transfer (RAFT) polymerization, etc. [41] enable various architectures of polymer materials (linear free chains in solution, permanently and physically cross-linked hydrogels, amphiphillic block and graft copolymers (micelles) and modified surfaces (polymer brushes) and membranes), each of them having characteristic adsorption properties. Additionally, this type of adsorbents can be easily and completely regenerated with no significant decrease in sorption capacities [42], while by choosing the appropriate monomer or comonomers, environmental friendly adsorbents causing neither direct nor indirect adversity to nature can be obtained. A list of synthetic polymer materials recently used for removal of azo-dyes is given in Table 3.

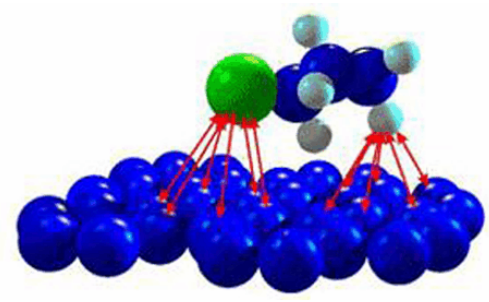

Figure 2. Illustration of adsorption process.

One of the most used forms of polymer materials in the adsorption field are hydrogels - a special type of polymeric materials with three-dimensional, cross-linked structure, able to uptake and retain large amounts of water or aqueous solutions without dissolving due to the presence of physical or chemical crosslinks [57]. During the swelling process of "smart" hydrogels, which could be tailored by external stimuli changes, the network expansion allows access of dye molecules to active centers in the interior of the material, making these materials very interesting to be used as adsorbents.

Poly( $N$-isopropylacrylamide-co-acrylic acid) (poly(NIPAAm-Co-AAc)) microgels and their assemblies were tested as adsorbents for the removal of an azo-dye Orange 2 from aqueous solutions [54]. It has been shown that removal efficiency critically depended on the concentration of $A A c$, the size of microgels and operating temperature, yielding a maximum removal efficiency of $56.6 \%$ by the microgels system with $10 \%$ AAc and a diameter of about $1.1 \mathrm{~mm}$ at elevated temperature. Microgel aggregates formed from those microgels using various concentrations of $\mathrm{N}, \mathrm{N}$-methylenebisacrylamide (MBA), were found to significantly improve the removal efficiency, because of the structure (i.e, hydrophobicity and internal volume) of the aggregates. The aggregates with $500 \mathrm{mg}$ MBA were able to remove $73.1 \%$ of Orange 2 , which is a significant enhancement compared with the unaggregated microgels. It was found that the concentration of MBA, as well as the size of microgels in the aggregates affects the percent uptake of the dye. Aggregates with large microgels resulted in notably higher removal of dye, comparing to aggregates of small microgels.

Poor mechanical properties of highly swollen polymer hydrogels can be enhanced through the preparation of interpenetrating polymer networks (IPNs), which are defined as a combination of two polymers in network form without any covalent bonds between them, or semi-IPN, when one of the components has a linear instead of network structure.

Üzüm and Karadag have investigated adsorption properties of a series of acrylamide based hydrogels modified with hydrophobic comonomers and semi-IPNs with poly(ethylene glycol) (PEG) as linear interpenetrant. They have shown that poly(acrylamide-co-sodium 
Table 3. Some synthetic polymer adsorbents, targeted dyes and corresponding adsorption capacities

\begin{tabular}{|c|c|c|c|}
\hline Polymeric adsorbent & Dye & Maximal adsorption capacity & Reference \\
\hline $\begin{array}{l}\text { Poly(glycidyl methacrylate) grafted sulfonamide } \\
\text { based polystyrene resin with tertiary amine }\end{array}$ & Everzol black & $980 \mathrm{mg} \mathrm{g}^{-1}$ & [43] \\
\hline $\begin{array}{l}\text { Poly(glycidyl methacrylate) grafted sulfonamide } \\
\text { based polystyrene resin with tertiary amine }\end{array}$ & Everzol red & $1000 \mathrm{mg} \mathrm{g}^{-1}$ & {$[41]$} \\
\hline $\begin{array}{l}\text { Poly(glycidyl methacrylate) grafted sulfonamide } \\
\text { based polystyrene resin with tertiary amine }\end{array}$ & Calcon & $1000 \mathrm{mg} \mathrm{g}^{-1}$ & [41] \\
\hline $\begin{array}{l}\text { Poly(ether sulfones)/poly(ethyleneimine) } \\
\text { (PES/PEI) nanofibrous membrane }\end{array}$ & Sunset Yellow FCF & $1000 \mathrm{mg} \mathrm{g}^{-1}$ & [44] \\
\hline $\begin{array}{l}\text { Poly(ether sulfones)/poly(ethyleneimine) } \\
\text { (PES/PEI) nanofibrous membrane }\end{array}$ & Amaranth & $454 \mathrm{mg} \mathrm{g}^{-1}$ & {$[42]$} \\
\hline Porous poly(vinyl alcohol) gels & Congo red & $35 \%$ & [45] \\
\hline Porous poly(vinyl alcohol) gels & Methyl Orange & Not available & [43] \\
\hline Poly (amidoamine-co-acrylic acid) copolymer & Direct Red 31 & $3400 \mathrm{mg} \mathrm{g}^{-1}$ & {$[46]$} \\
\hline Poly (amidoamine-co-acrylic acid) copolymer & Direct Red 80 & $3448 \mathrm{mg} \mathrm{g}^{-1}$ & [44] \\
\hline $\begin{array}{l}\text { Macroporous polystyrene cross-linked with } \\
\text { divinylbenzene (Purolite A-520E) }\end{array}$ & Acid Blue 29 & $48.2 \mathrm{mg} \mathrm{g}^{-1}$ & {$[47]$} \\
\hline Poly(1-naphthylamine) & Acid Orange 10 (Orange G) & $328 \mathrm{mg} \mathrm{g}^{-1}$ & {$[45]$} \\
\hline Poly(1-naphthylamine)-camphorsulphonic acid & Acid Orange 10 (Orange G) & $315 \mathrm{mg} \mathrm{g}^{-1}$ & {$[45]$} \\
\hline Poly(N-vinyl-2-pyrrolidone) & Congo red & Not available & {$[48]$} \\
\hline Poly(N-vinyl-2-pyrrolidone) & Methyl orange & Not available & {$[46]$} \\
\hline Cross-linked poly(styrene) resins & Acid red 14 & Not available & [49] \\
\hline $\begin{array}{l}\text { Poly( } N, N \text {-dimethylacrylamide-co-sodium acrylate) } \\
\text { hydrogel }\end{array}$ & Basic Blue 41 & $710 \mathrm{mg} \mathrm{g}^{-1}$ & [50] \\
\hline $\begin{array}{l}\text { Poly( } N \text {-vinyl-2-pyrrolidone-co-acrylonitrile) } \\
\text { treated with hydroxylamine-hydrochloride }\end{array}$ & Acid fast yellow $\mathrm{G}$ & $7.6 \mathrm{mg} \mathrm{g}^{-1}$ & {$[51]$} \\
\hline $\begin{array}{l}\text { Poly( } N \text {-vinyl-2-pyrrolidone-co-acrylonitrile) } \\
\text { treated with hydroxylamine-hydrochloride }\end{array}$ & Direct blue 3B & $7 \mathrm{mg} \mathrm{g}^{-1}$ & [49] \\
\hline $\begin{array}{l}\text { Poly( } N \text {-vinyl-2-pyrrolidone-co-acrylonitrile) } \\
\text { treated with hydroxylamine-hydrochloride }\end{array}$ & Reactive red SH & $7.4 \mathrm{mg} \mathrm{g}^{-1}$ & [49] \\
\hline Poly(acrylamide-co-acrylic acid) hydrogels & Janus Green B & $44 \mathrm{mg} \mathrm{g}^{-1}$ & {$[52]$} \\
\hline Poly(acrylamide-co-sodium acrylate) hydrogels & Janus green B & $7 \times 10^{-4} \mathrm{~mol} \mathrm{~g}^{-1}$ & [53] \\
\hline $\begin{array}{l}\text { Poly(acrylamide-co-sodium } \\
\text { acrylate)/poly(ethylene glycol) semi-IPN }\end{array}$ & Janus green B & $6.33 \times 10^{-4} \mathrm{~mol} \mathrm{~g}^{-1}$ & [51] \\
\hline Poly(acrylamide-co-sodium 4-styrenesulfonate) & Janus green B & $67 \%$ & {$[54]$} \\
\hline $\begin{array}{l}\text { Poly(acrylamide-co-sodium 4- } \\
\text { styrenesulfonate)/poly(ethylene glycol) semi-IPN }\end{array}$ & Janus green B & $62 \%$ & {$[52]$} \\
\hline $\begin{array}{l}\text { Poly(acrylamide-co-sodium methacrylate) } \\
\text { hydrogels }\end{array}$ & Janus green B & $90 \%$ & {$[55]$} \\
\hline $\begin{array}{l}\text { Poly(acrylamide-co-sodium } \\
\text { methacrylate)/poly(ethylene glycol) semi-IPN }\end{array}$ & Janus green B & $87 \%$ & [53] \\
\hline $\begin{array}{l}\text { Poly( } N \text {-isopropylacrylamide-co-acrylic acid) } \\
\text { microgel assemblies }\end{array}$ & Orange 2 & $73 \%$ & [56] \\
\hline
\end{tabular}

acrylate) (poly(AAm-co-SA)), poly(acrylamide-co-sodium-4-styrenesulfonate) (poly(AAm-co-NaSS)) and poly(acrylamide-co-sodium methacrylate) (poly(AAm-co-SMA) hydrogels and (poly(AAm-Co-SA)/PEG, poly(AAmco-NaSS)/PEG and semi-IPNs have ability to adsorbe the monovalent cationic dyes, such as Janus green $B$ (JGB), whereas poly(acrylamide) (PAAm) does not [51-53]. The incorporation of hydrophilic groups such as sodium acrylate (SA) or 4-styrenesulfonic acid sodium salt and a polymer such as poly(ethylene glycol) in PAAm hydrogels was obtained successfully by free radical solution polymerization. The amount of JGB adsorbed onto unit dry mass of the gel increased with the content of $S A$, together with equilibrium swelling degree, reaching maximal value when AAm/SA weight ratio was $12.5: 1$, while there was no important change 
of the dye removal capacity of AAm/SA/PEG semi-IPN systems when PEG has been added. Similar behavior was noticed for the system with NaSS and SMA instead of SA. Swelling and adsorption capability of corresponding hydrogels and semi-IPNs are increased with increasing NaSS, i.e., SMA, content in copolymeric structure due to the increased hydrophilicity of network and number of possible interactions in binding of JGB by investigated adsorbents. Among the three above-mentioned hydrophilic comonomers, introduction of sodium methacrylate is found to provide the best adsorption characteristics, as can be seen from the data listed in Table 3.

The same group has shown that poly(acrylamide-co-itaconic acid) hydrogels prepared by irradiating with $\gamma$ radiation were also able to remove azo dyes from wastewater [58].

Therefore, the adsorption capacity of a polymeric adsorbent toward specified dye or group of dyes can be improved by introduction of monomers that have different functional groups due to the specific interaction of functional groups bound to the polymeric matrixes with the target pollutants, but also by modification of existing groups on polymer chains $[59,60]$.

Linear polymers grafted onto crosslinked polymer resin particles offer numerous potential applications due to the combination of the non-solubility resin and the flexibility of the graft polymer side-chains as the functional group carrier. The flexible side-chains can provide pseudo-homogeneous reaction conditions and better accessibility of involved active centers. Senkal et al. have synthesized poly(glycidyl methacrylate) grafted sulfonamide based polystyrene resin with tertiary amine which has been shown to be an efficient adsorbent for removal of azo dyes from water as a result of tertiary amine group's affinity towards dye molecules [41]. A beaded polymer with a poly(glycidyl methacrylate) (PGMA) surface shell was prepared in three steps, starting from poly(styrene-divinyl benzene) based beads. The synthetic protocol included chlorosulfonation, sulfamidation with 2-chloroethylamine hydrochloride and grafting reaction of PGMA. Graft polymerization of GMA from polystyrene resin-supported 2-chloroethyl sulfonamide groups was carried out using atom transfer radical polymerization (ATRP). When graft chains were attached to the resin with stable sulfonamide linkages, this material could be modified via epoxy groups to impart any desired functionality in mild reaction conditions. The polymeric resin was subsequently modified with diethyl amine to introduce tertiary amine groups that enable very good adsorption properties. Even though obtained adsorption capacities for removal of employed azo dyes were very high over a wide $\mathrm{pH}$ range, it is determined that increase in $\mathrm{pH}$ from 2 to 8 , leads to increase in adsorption capacities from 600 to $890 \mathrm{mg} \mathrm{g}^{-1}, 580$ to $910 \mathrm{mg} \mathrm{g}^{-1}$ and 620 to $850 \mathrm{mg} \mathrm{g}^{-1}$, for Everzol black, Everzol red and Calcon, respectively. This adsorbent has also shown to be easily regenerated by using basic methanol and $0.1 \mathrm{M} \mathrm{HCl}$, recovering about $94.4 \%$ of dye.

Copolymer hydrogels based on $\mathrm{N}$-vinyl-2-pyrrolidone (NVP) and methyl methacrylate (MMA) or acrylonitrile (AN) were prepared by $\gamma$-irrradiation copolymerization [49]. The nitrile groups $(-\mathrm{CN})$ in the prepared copolymer were subsequently treated with hydroxylamine-hydrochloride and converted into amidoxime groups that have an affinity for the anions of the reactive, acid and direct dye molecules. Such a process resulted in improving both the swelling behavior and adsorption capacity, thus in all experiments treated poly(NVP-co-AN) hydrogel showed higher affinity toward dye uptake compared to poly(NVP-co-MMA) and untreated poly(NVP-Co-AN). The adsorption of the pollutants on prepared hydrogels was investigated at various $\mathrm{pH}$ values. The uptake of decreases with increasing $\mathrm{pH}$, until it reaches its minimum value at $\mathrm{pH}$ 10. For acid dye, the dye uptake decreases with increasing $\mathrm{pH}$, up to $\mathrm{pH} \mathrm{7,} \mathrm{then} \mathrm{starts} \mathrm{to} \mathrm{increase} \mathrm{at} \mathrm{a}$ faster rate beyond $\mathrm{pH} 7$.

A few possible ways of bonding are usually involved in dye adsorption on polymer materials: hydrogen bonding, ion exchange, electrostatic and hydrophobic interactions [61]. Analyzing the composition of treated poly(NVP-co-AN) and the structure of used dyes, it was concluded that electrostatic interactions together with hydrophobic interactions and hydrogen bonding could occur between cationic groups of NVP and anionic groups of the dyes. Hydrophobic effects, which are specifically aqueous solution interactions, in the present case would involve the aromatic rings and the methyl and methine groups on the dye molecules and methine groups on the gel. Hydrogen bonding could be expected to occur between amine groups of the oxygen atom on the dye molecules and the carbonyl groups on the monomer units of the crosslinked copolymer.

In case of many listed synthetic polymer adsorbents, it is proven that they show strong $\mathrm{pH}$-dependent behavior. Bearing in mind that most of the used polymer materials, as well as azo dyes, are ionic in nature, it is expected that the solution $\mathrm{pH}$ affects the structure of the dye as well as the structure of the polymeric material itself, has significant influence on the surface changes of the adsorbents, the degree of ionization of present functional groups, and as a consequence, onto the investigated adsorption process [62]. If mechanism of dye uptake is attributed to the electrostatic attraction force between the dye and the polymeric material, at adequate $\mathrm{pH}$, charged groups on polymer chains would be free to promote electrostatic interactions with dye ions. Any change in either charge would affect the 
uptake percentage. Novel micro-nano structure poly(ether sulfones)/poly(ethyleneimine) (PES/PEI) nanofibrous membranes have been synthesized and utilized as adsorbents for removal of anionic azo-dyes Sunset Yellow FCF Amaranth [42] . A series of adsorption experiments were carried out to investigate the influence of membrane dosage, initial solution $\mathrm{pH}$ value, contact time, initial solution concentration and adsorption temperature on the adsorption performance. Polyethyleneimine (PEI) has a large amount of amino and imino groups in its polymer chain. The experimental results showed that the removal of the anionic dyes on this PES/PEI nanofibrous membrane was a $\mathrm{pH}$-dependent process with the maximum adsorption capacity at the initial solution $\mathrm{pH}$ of 1 . The adsorption equilibrium data were all fitted well to the Langmuir isotherm equation, with maximum adsorption capacity values of $1000 \mathrm{mg} \mathrm{g}^{-1}$ and $454.4 \mathrm{mg} \mathrm{g}^{-1}$, for Sunset Yellow FCF and Amaranth, respectively. Solution $\mathrm{pH}$ had shown a significant effect on the uptake of dyes, since it determined the surface charge of the adsorbent and the degree of ionization and speciation of the dyes. At low $\mathrm{pH}$ solution a relatively high concentration of protons was available to protonate amine and imino groups $\left(-\mathrm{NH}_{2}\right.$ and $\left.-\mathrm{NH}-\right)$ on $\mathrm{PEI}$, forming $-\mathrm{NH}_{3}{ }^{+}$and $-\mathrm{NH}_{2}{ }^{+}-$ groups capable to attract dye anions. The electrostatic interactions between the PES/PEI nanofibrous membrane and the anionic dyes were proven by $\mathrm{x}$-ray photoelectron spectroscopy (XPS). The results have also shown that the adsorption capacity of of PES/PEI nanofibrous toward tested dyes increased with increasing initial dye concentrations because of the increase in the driving force of concentration gradient with an increase in the initial concentration, but then tended to level off when complexes between the chelating sites and the absorbates reached saturation.

In order to prove the outstanding effect of PEI component in PES/PEI nanofibrous affinity membranes, the pure PES nanofibrous membrane was also used for removal the anionic dyes. The maximum adsorption capacity of pure PES nanofibrous membranes for SY FCF and AM were very low $\left(4.2\right.$ and $3 \mathrm{mg} \mathrm{g}^{-1}$, respectively) indicating that $\mathrm{PES}$ functioned mainly as a matrix.

As can be seen from Table 3, by far the best results regarding adsorption capacities of synthetic polymer materials for azo-dyes are reported for poly(amidoamine-co-acrylic acid) copolymer use for removal of direct dyes, Direct Red 31 and Direct Red 80 [44]. The adsorption capacity increases when the $\mathrm{pH}$ is decreased. Maximum adsorption of anionic dyes occured at acidic $\mathrm{pH} 2$, where significantly high electrostatic attraction existed between the positively charged $\left(-\mathrm{NH}_{3}{ }^{+}\right)$surface of the PAC and negatively charged anionic dye. As the $\mathrm{pH}$ of the system increases, the number of positively charged sites decreased, as well as the adsorption efficiency of PAC. An important limitation resulting from the high reactivity and nonselectivity of adsorbent that reacts with non-target compounds was noticed in the presence of inorganic salts, because these salts have small molecules and compete with dyes for the same adsorption sites on PAC. It results in a higher adsorbent dosage demand to accomplish the desired degree of dye removal efficiency.

In literature are also reported $\mathrm{pH}$ independent polymer adsorbents, such as poly(1-naphthylamine) (PNA) and PNA doped with camphor-sulphonic acid (CSA) used for sulphonate azo dye Acid Orange 10 removal from acidic and basic medium [45]. In that case adsorption predominantly occurs through hydrophobic interactions, i.e. strong van der Waals attraction between naphthalene groups of PNA and Acid Orange 10 dye.

It could be concluded that some of proposed adsorbents have shown limited ability to remove the employed dye, while with the others the ability of potential development and application was noted.

\section{NATURAL POLYMERS}

Natural polymers represent an interesting and attractive alternative as adsorbents because of their particular structure, physico-chemical characteristics, chemical stability, high reactivity and excellent selectivity towards heavy metal ions and dyes, resulting from the presence of reactive chemical groups in polymer chains. Much attention has recently been focused on polysacharides such as starch, alginate, cyclodextrin, cellulose and chitosan. It is well known that polysaccharides which are abundant, renewable and biodegradable resources have a capacity to associate by physical and chemical interactions with a wide variety of molecules. Hence adsorption onto polysaccharide derivatives can be a low-cost and feasible procedure of choice in water decontamination. Compared with conventional sorbents for removing pollutants from solution, such as commercial activated carbons and synthetic ion-exchange resins, the advantage of polysaccharide based adsorbent is possibility of easy regeneration if its required. The main disadvanteges of polysaccharide adsorbents are their low porosity, $\mathrm{pH}$ dependence and dependence of different sources of raw materials, so there is increasing interest in modification of these materials to enhance adsorption capacity.

\section{Starch}

Next to cellulose, starch is the most abundant carbohydrate in the world and is present in living plants as energy storage material. Starches are mixtures of two polyglucans, amylopectin and amylose, but they contain only a single type of carbohydrate, glucose (Figure 3). 


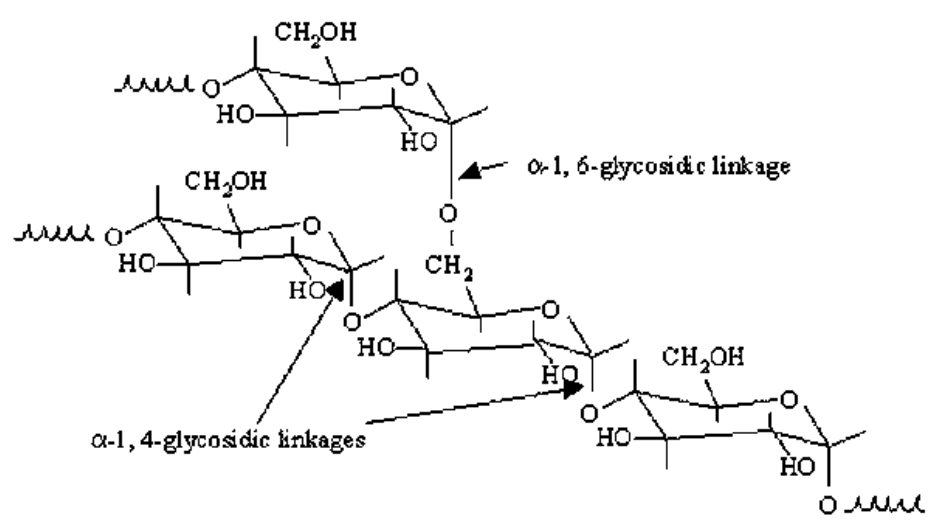

Figure 3. Starch structure.

Amylose is nearly unbranched, while amylopectin is highly branched with the branches connected in $\alpha-1,6$ position of the anhydroglucose unit [63].

Starches are unique raw materials, inexpensive and widely available in many countries. They possess several other advantages which make them excellent materials for industrial use. However, the hydrophilic nature of starch is a major constraint which seriously limits the development of starch-based materials. Chemical derivatisation has been proposed as a way to solve this problem and to produce water resistant adsorbents.

Very important feature is the possibility of starch to adsorb water. This ability comes from interaction of free $-\mathrm{OH}$ groups on the glucose units and the water molecules (Figure 4) [64,65].

The hydroxyl groups interact with water molecules by hydrogen bonding. Van den Berg et al. proposed that the Brunauer, Emmett and Teller equation (BET) could be related to the number of adsorption sites on starch, because the monolayer capacity is found to be strongly related to the number of polar groups that are able to adsorb water on the starch surface [66].
Both types of starch chains, amylose and amylopectin, establish hydrogen bonds with water molecules. Amylopectin structures also physically trap water molecules in the matrix of chain branches in the amorphous portion of the starch. When the water molecules are trapped in this way, some of the nearby $-\mathrm{OH}$ groups hydrogen bond with the trapped water molecule and become unavailable for additional hydrogen bonding. The amylopectin branched structure has overlapping hydroxyl groups which are proposed to correspond to more hydroxyl groups per unit area of the starch surface. Thus an adsorbent high in amylopectin is hypothesized to have a greater adsorption capacity [64].

As a biodegradable biomass, starch has attracted considerable attention since it can be modified to remove heavy metal ions and dyes [67-70]. In order to test the dye adsorption numerous modifications of starch were investigated. Cationic starch derivatives containing primary, secondary, and tertiary amino groups and quaternary ammonium salt and etherified and grafted cationic starch derivatives were treated with three types of dyes - an acid dye, a hydrolyzed reactive dye, and a direct dye in order to determinate

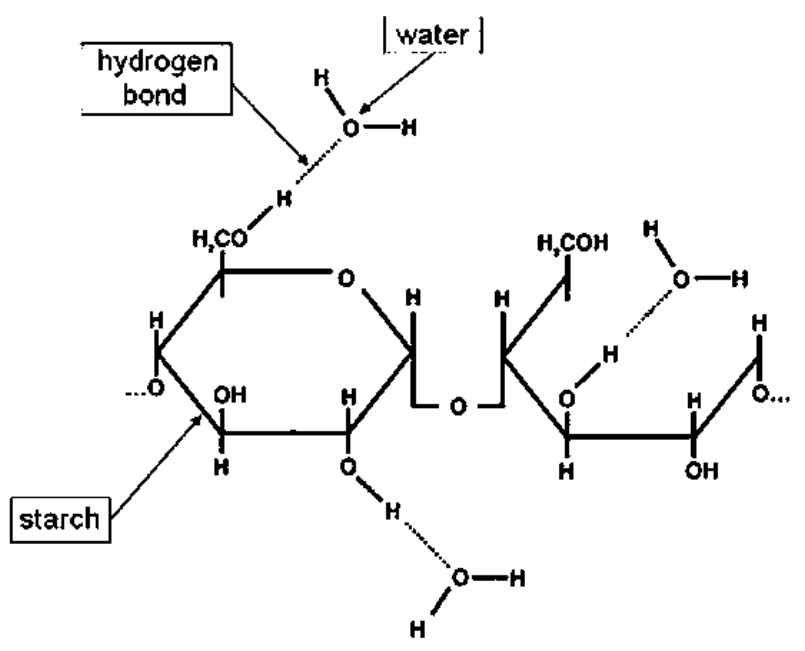

Figure 4. Hydrogen bonding of water to starch molecules. 
factors affecting the dye sorption value [71]. The dye sorption value increased with increasing amine content to a maximum value and then decreased for all amine types. The maximum sorption depends on the dye type: acid dye >hydrolyzed reactive dye > direct dye. The cationic starch ethers were better adsorbents for dyes than the grafted cationic starch derivatives. The dye sorption value increased with increasing $\mathrm{pH}$; the maximum dye sorption value of the direct dye was at $\mathrm{pH} 4$, whereas those for the acid and hydrolyzed reactive dyes were at $\mathrm{pH} 5$ [72].

Crosslinked starch-based adsorbents are an important class of starch derivatives. The crosslinked polymeric materials have a three-dimensional network structure and can swell in aqueous medium without dissolution [73].

Klimaviciute et al. studied the adsorption of anionic dyes Acid Yellow 36, Acid Orange 7, Acid Orange 52, Acid Red 151 on the crosslinked materials with epichlorohydrin starches containing quaternary ammonium groups. The adsorption of all investigated dyes by the cationic starches with different groups increased in the following order: primary amino $<$ secondary amino $<$ $<$ tertiary amino < quaternary ammonium groups. The adsorption of the dyes by the cationic starches having primary, secondary and tertiary amino groups can be effectively only in the acid solution. In alkaline and acid solutions of dyes only quaternary ammonium groups can effectively work. It is shown that starches crosslinked with epichlorohydrin containing quaternary ammonium groups are more suitable for the anionic dye adsorption from a textile dyeing solution compared with modified starches containing only quaternary ammonium groups [74]. Crosslinked amphoteric starch with carboxymethyl and quaternary ammonium groups was investigated for removal of Acid Light Yellow 2G and Acid Red G, by Xu et al. [75]. It was noticed that the residual concentration of the Acid Red $G$ decreased abruptly when the $\mathrm{pH}$ value was above 10 due to the presence of negatively charged phenolic hydroxyl groups which can become potentially active sites and could attracted by the ammonium groups in the absorbents. The maximum adsorption capacity was 113,6 and 135,6 $\mathrm{mg} \mathrm{g}^{-1}$ for Acid Yellow $2 \mathrm{G}$ and Acid Red $\mathrm{G}$ dye, respectively.

Ju studied the discoloration of cationic starch with different degrees of substitution (DS) for C.I. Reactive Red 2 and C.I. Reactive Yellow 145 [76]. It was found that cationic starch with a higher DS had high adsorption capacity. When DS increased from 0.37 to 0.70 , dye uptake increased from 45.9 and $53.4 \%$ to 59.2 and 67.1\% for C.I. Reactive Red 2 and C.I. Reactive Yellow 145 , respectively.

Delvala et al. used crosslinked polysaccharides derivatives containing tertiary amine groups to recover various textile dyes in aqueous solutions. The crosslinked polymers have been prepared in one step by reticulation of starch-enriched flour using only epichlorohydrin as cross-linking agent in the presence of $\mathrm{NH}_{4} \mathrm{OH}$. Polysaccharides form insoluble gels on reaction with epichlorohydrin (EPI) under alkaline conditions and in this way weakly basic anion-exchange groups were introduced into polymer matrices. Among others, the adsorption of two azo dyes: Acid Red 1 and Acid Red 40 was studied. The result shows that the presence of amino groups and the nature of the dye could influence the adsorption capacity. This adsorbent can be applied on both acid and basic dyes. For acid dyes, the active sites are the quaternary ammonium groups, while for basic dyes, they are carboxymethyl groups. The adsorption processes are exothermic for acid dyes, which mean that low temperature will facilitate the adsorption, while the basic dyes have the highest adsorption capacity at $303 \mathrm{~K}$ [77].

Cheng et al. investigated starch modified with etylenediamine for removal of Acid Orange 10 (AO10), Acid Green 25 (AG25) and Amido Black 10B (AB10B) [78]. The maximum capacity for each dye at $\mathrm{pH}$ value of 4 was achieved. The adsorption of $A G 25$ and $A B 10 B$ followed pseudo-second-order model, whereas adsorption of AO10 could be adequately described by both models. According to the Langmuir equation the capacities followed the sequence $A B 10 B(1.1 \mathrm{mmol} / \mathrm{g})>$ AG25 (0.8 mmol/g) > AO10 (0.6 mmol/g). Wang et al. investigated native and enzymatic hydrolyzed starch modified with diethylenetriamine for removal of Acid Orange 7 (AO7), AO10, AG25 and Acid Red 18 (AR18) [79]. In all cases the modified hydrolyzed starch had higher adsorption capability than modified native starch. With increase of grafting groups, the adsorption of dyes increased on modified hydrolyzed starch. Increments of the sorption capacities for the four acid dyes was higher than values obtained by Cheng et al. and the sequence of $A 07\left(2,5 \mathrm{mmol} \mathrm{g}^{-1}\right)>\operatorname{AO} 10\left(1,2 \mathrm{mmol} \mathrm{g}^{-1}\right)$ $>\operatorname{AR} 18\left(1,6 \mathrm{mmol} \mathrm{g}^{-1}\right)>\operatorname{AG} 25\left(1,8 \mathrm{mmol} \mathrm{g}^{-1}\right)$. Cheng et al. also investigated dithiocarbamate-modified starch (DTCS) for removal of AO7, AO10, AR18, AG25, Acid Black 1 (AB1) [80]. With the increase of $\mathrm{pH}$ value, the adsorption capacity for each dye decreased dramatically. The authors suggested that in acidic medium, positive surface charge is developed due to protonation of dithiocarbamate which increased with in decrease in $\mathrm{pH}$ of dye solution. The capacities for individual dyes follow the sequence $A O 7(0.8 \mathrm{mmol} / \mathrm{g})>\mathrm{AO} 10(0.4$ $\mathrm{mmol} / \mathrm{g})>\mathrm{AB} 1(0.38 \mathrm{mmol} / \mathrm{g})>\mathrm{AR} 18(0.37 \mathrm{mmol} / \mathrm{g})>$ AG 25 (0.31 mmol/g).

\section{Alginate}

Alginates are unbranched polysaccharides consisting of 1-4 linked $\beta$-D-mannuronic acid (M) and its C-5 epimer $\alpha$-L-guluronic acid (G) (Figure 5). It is comprised 


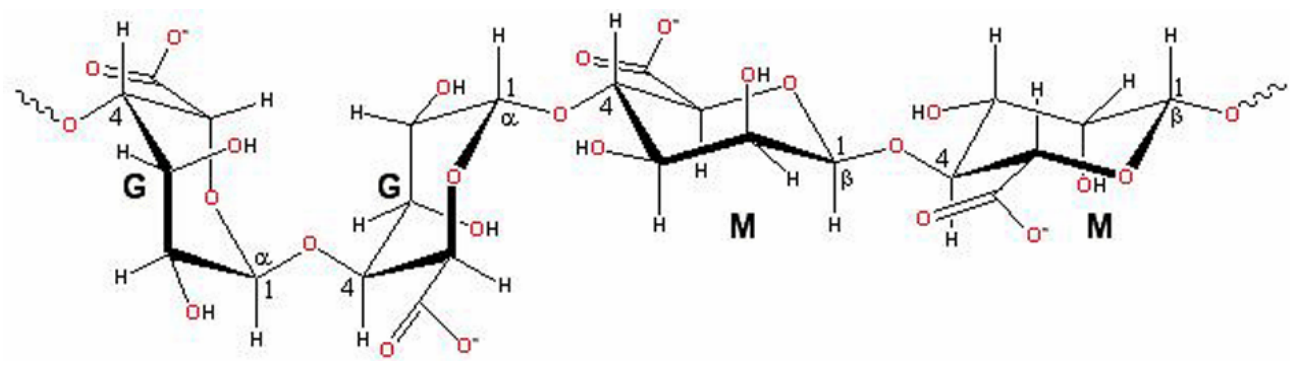

Figure 5. Alginate structure.

of sequences of $M$ (M-blocks) and $G$ (G-blocks) residues interspersed with MG sequences (MG-blocks). While it is possible to obtain alginates from both algal and bacterial sources, commercially available alginates currently come only from algae. The copolymer composition, sequence and molecular weights vary with the source and species that produce the copolymer. The combination of chemical and biochemical techniques provides considerable potential for creating modified alginic acid derivatives with control over monosaccharide sequence and nature, location and quantity of substituents [81].

One of the important properties of alginate is the ability to form hydrogels and has the capacity to remove toxic pollutants $[82,83]$. An aqueous solution of alginate is readily transformed into a hydrogel on addition of metallic divalent cations. Calcium alginate immobilized microbial cultures have been used to remove dyes, Reactive Black 22 and Direct Black 22 [84]. The beads from $0.05 \mathrm{M}$ concentration of the $\mathrm{CaCl}_{2}$ solution had the lowest resistance to compression compared to those cross-linked in $\mathrm{CaCl}_{2}$ solutions with higher concentrations. Decoloration rate of the softer beads was higer probably because lower $\mathrm{CaCl}_{2}$ concentrations resulted in fewer cross-links at the guluronic acid binding sites leading to weaker cohesion in the alginate matrix to allow better diffusion through the bead. Decoloration has been shown to follow firstorder kinetics with respect to dye concentration.
Alginate could be effectively used as a biosorbent for the removal of cationic dyes. The alginate biosorbent exhibited high sorption capacities toward Basic Red 18 and Basic Blue 41 which were used as model compounds in single and binary systems. Adsorption is increased with increase in adsorbent dosage and this can be attributed to reduced availability of adsorption sites. The equilibrium capacity depends on initial dye concentration and decreases with an increase in this values. At low initial dye concentrations, the adsorption of dyes by alginate is very intense and reaches equilibrium very quickly which indicates the possibility of the formation of monolayer coverage of the molecules at the outer interface of the alginate. When the $\mathrm{pH}$ increases the adsorption capacity increases and the maximum adsorption of basic dyes occurs at $\mathrm{pH} 8$. This $\mathrm{pH}$ value provides a considerably high electrostatic attraction exists between the negatively charged surface of the adsorbent, due to the ionization of functional groups of the adsorbent and positively charged cationic dye molecules [85].

\section{Cyclodextrin}

Cyclodextrins (CDs) comprise a family of three wellknown industrially produced substances. The practically important, industrially produced $\mathrm{CDs}$ are the $\alpha-, \beta$-, and $\gamma$-cyclodextrins (Figure 6). The three major cyclodextrins are crystalline, homogeneous, nonhygroscopic substances, built up from glucopyranose units. The $\alpha$-cyclodextrin comprises six glucopyranose units,
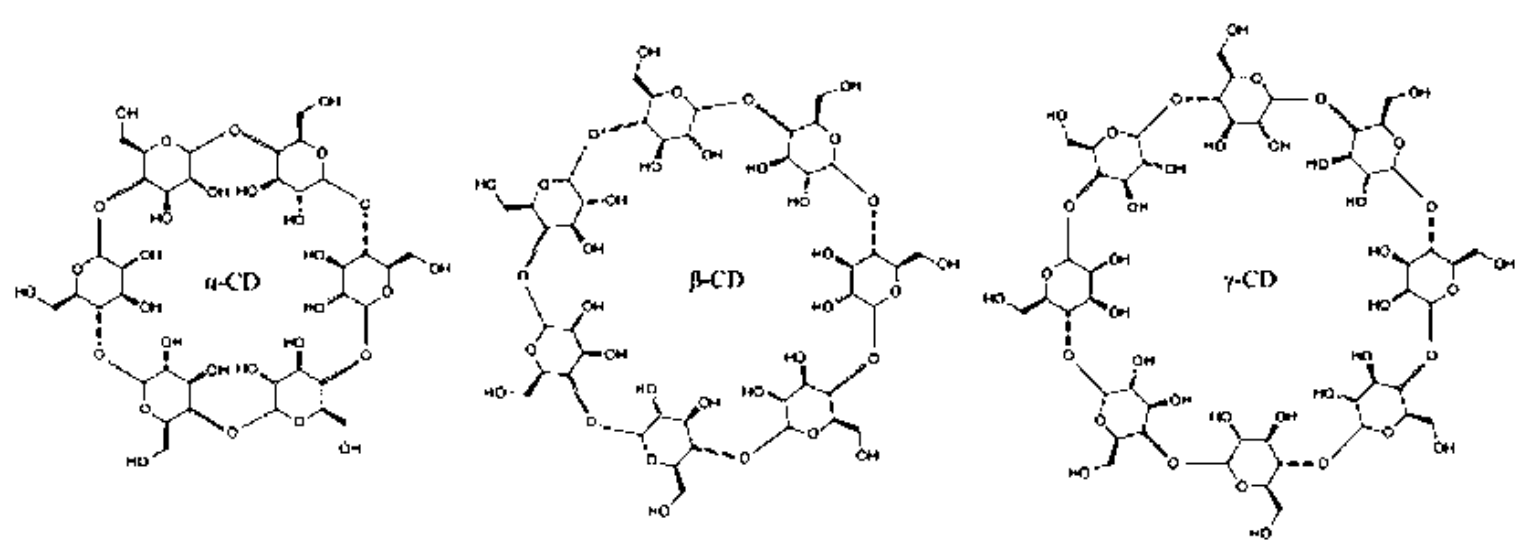

Figure 6. $\alpha-, \beta$, and $\gamma$-cyclodextrin structures. 
$\beta$-cyclodextrin comprises seven such units, and $\gamma$-cyclodextrin comprises eight such units. Cyclodextrins can be obtained by enzymatic degradation of starch. In this process compounds with six to twelve glucopyranose units per ring are produced. Depending on the enzyme and the way thereaction is controlled, the main product is $\alpha-, \beta$ - or $\gamma$-cyclodextrin $(6,7$ and 8 glucopyranose units, respectively).

The most notable feature of cyclodextrins is their ability to form solid inclusion complexes ("host-guest" complexes) with a very wide range of solid, liquid and gaseous compoundsby a molecular complexation. In these complexes a guest molecule is held within the cavity of the cyclodextrin host molecule. Cyclodextrin inclusion is a stoichiometric molecular phenomenon in which usual only one guest molecule interacts with the cavity of the cyclodextrin molecules to become entrapped. $1: 1$ complex is the simplest and most frequent case. However, 2:1, 1:2, 2:2, or even more complicated associations, and higher order equilibrium exist almost always simultaneously. The ring structure of cyclodextrins allows them to act as hosts and form inclusion compounds with various small molecules which provides them good application in textile industry for removing of certain dyes [86].

Cyclodextrin polymers were modified using hexamethylene diisocyanate (HMDI) as a cross-linking agent in dry dimethylformamide and used as a sorbent for the removal of some selected azo dyes from aqueous solutions. Cyclodextrin based materials were used to remove the following dyes: direct violent 51 (DV-51), methyl orange (MO), and tropaeolin 000 (TP). These materials exhibit approximately same sorption capacity toward all the azodyes except DV-51 which contains more sulfonates and azogroups than the others. This is due to establishment of intermolecular hydrogen bonds between hydroxyl and amide groups in the polymer and between sulfonate groups of DV-51 [87]. These results were in agreement with the literature data published by using $\beta$-CD based polymers with epichlorohydrin [21]. The values of the adsorption capacity for DV-51 increased with increasing of the $\mathrm{pH}$ as always in the case of the inclusion complex with $\beta$-CD and aromatic derivatives [88]. The sorption was dependent on the presence of amide and sulfonate groups and according to this, it assumed that in the adsorption mechanism, hydrogen bonding, hydrophobic interactions (pollutant-polymer and pollutant-pollutant interactions), complexation and acid-base interactions between the sorbent and the pollutant, physical adsorption due to the polymer network and chemical interactions of solute dyes via ion exchange are all involved. The same modification of cyclodextrin using HMDI was reported for efficiently removal of Titanium Yellow (TY) and Direct Blue 71 (DB 71) [89]. The maximum sorption capacity these materials had shown for the removal of Titanium Yellow from an aqueous solution (52\%). Cyclodextrin cross-linked using 4,4'-methylene bisphenyldiisocyanate (MDI) was also used for removal of azo dyes (Evans Blue and Chicago Sky Blue) and is turned to be efficient extractant. It is shown that cyclodextrin modified with MDI has higher values of adsorption capacity compare to cyclodextrin modified with HMDI. According to Langmuir sorption equation, maximum capacity of $12.09 \mathrm{mmol} \mathrm{g}^{-1}$, was determined for the adsorption of Evans Blue [23].

\section{Cellulose}

Cellulose is a renewable resource and one of the most abundant organic materials on the planet. Cellulose is mostly obtained from wood pulp and cotton. Cellulose content in cotton can be up to $94 \%$, while this content in wood pulp is lower due to presence of lignin, but it's still above $50 \%$. Cellulose can also be made by bacteria and is thus called microbial or bacterial cellulose.

The molecular structure of cellulose comprises of repeating $\beta$-D-glucopyranose units which are covalently linked through acetal functions between the $\mathrm{OH}$ group of the $\mathrm{C} 4$ and $\mathrm{C} 1$ carbon atoms ( $\beta$-1,4-glucan) (Figure 7). Cellulose is a large, linear-chain polymer with a large number of hydroxyl groups (three per anhydroglucose (AGU) unit) and present in the preferred 4C1 conformation. To accommodate the preferred bond angles, every second AGU unit is rotated 180 in the plane. The length of the polymeric cellulose chain depends on the number of constituent AGU units (degree of polymerisation, DP) and varies with the origin and treatment of the cellulose raw material [90].

There are four different polymorphs of cellulose: cellulose I, II, III and IV (Figure 8). Cellulose I, native cellulose, is the form found in nature, and it occurs in two allomorphs, $\mathrm{I} \alpha$ and $\mathrm{I} \beta$. Cellulose II, or regenerated

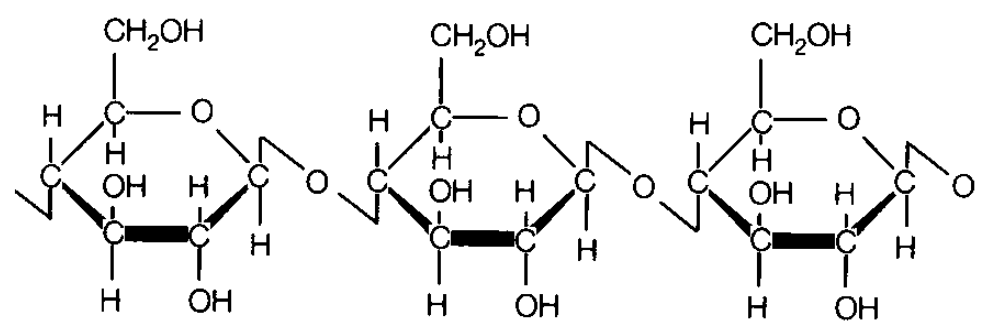

Figure 7. Chemical structure of cellulose. 


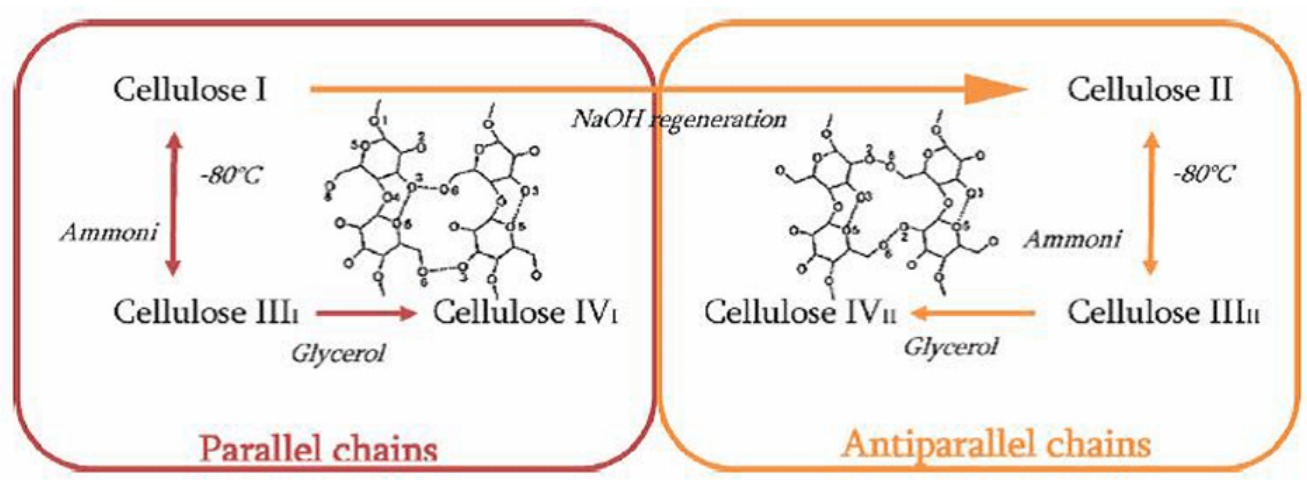

Figure 8. Polymorphs of cellulose.

cellulose, emerges after re-crystallization or mercerization with aqueous sodium hydroxide. It is the most stable crystalline form. The major distinction between these two forms of cellulose lies in the layout of their atoms: cellulose II has antiparallel packing, whereas the chains in cellulose I are in a parallel direction. Cellulose III is obtained by ammonia treatment of cellulose I or II, and cellulose IV is finally produced from cellulose III by treatment with glycerol [91,92]. Three hydroxyl groups in each $\beta$-D-glucopyranose units are able to interact with one another forming intra and intermolecular hydrogen bonds.

Cellulose in its form as a polymer raw material have been used mainly in two general areas: one being the use in constructing materials based on wood and cotton and also paper and board. The accessibility of cellulose depends on its origin, processing condition, and composition, i.e., index of crystallinity (Ic), degree of polymerization (DP), and contents of cellulose, hemicellulose, and lignin. Also cellulose has been widely used as a starting material for chemical reactions in attempt of create cellulose based artifacts that can be used in a medicine, pharmacy, bioenergy and wastewater applications [94-97]. The utilization of cellulose as a bioaffinity carrier material should enhance the adsorption of organic wastes due to its abundant hydroxyl groups, which give cationic nature to the biopolymer. The beads, films and resins based on natural cellulose were used to adsorb heavy metals and hazardous azo dyes. However, conventional bioadsorbents based on cellulose are difficult to be separated and recovered except by high speed centrifugation or filter. Also, as the molecular structure of cellulose itself is compact and inactive, it is inefficient for dye removal without any modification. Thus, proper treatment is required to introduce reactive sites and activate the sorption ability.

Buvaneswari et al. investigated the adsorption of Methyl Orange onto cellulose surface. The influence of different parameters such as $\mathrm{pH}$, temperature and concentration of dye solution on adsorption capacity was studied [98]. The optimum value of $\mathrm{pH}$ for adsorp- tion of Methyl Orange was 6, while with further increase of $\mathrm{pH}$ of dye solution percentage of adsorption decreased. The adsorption of Methyl Orange slightly increased up to $40{ }^{\circ} \mathrm{C}$ and further increase of temperature decreased the adsorption due to the collapse of hydrogen bonds.

Siroky et al. investigated the effect of alkali treatment in range of $\mathrm{NaOH}$ from $0-7.2 \mathrm{~mol} \mathrm{dm}^{-3}$ on $\mathrm{Cl}$ Reactive Red 120 sorption behaviour onto cellulose II [99]. It was observed that greatest adsorption of dye onto cellulose II occured for samples treated with 3.3 and $2.5 \mathrm{~mol} \mathrm{dm}^{-3}$ aqueous $\mathrm{NaOH}$ solution and reached adsorption capacity up to $80 \mathrm{mg} \mathrm{g}^{-1}$. With further increase of $\mathrm{NaOH}$ concentration, the adsorption capacity decreased. Pores in the celullose II significantly affected by alkali treatment ( $<2 \mathrm{~nm}$ diameter) and accessibility of dye $(1.4 \mathrm{~nm})$ sorption into those pores account the differences observed herein.

The adsorption of the anionic dyes $\mathrm{Cl}$ Reactive Red 120, Yellow and $\mathrm{Cl}$ Direct Blue 1 on cellulose fixed with reactive dyes having six and eight sulfonate groups was investigated to elucidate the co-ion repulsion effect on the adsorption of anionic dyes [100]. The amounts of dye adsorption on reactively dyed cellulose decreased by the repulsive effect of the sulfonate groups of the reactive dyes fixed previously. The larger amounts of fixed dye and lower ionic strength influenced decreasing of the adsorption, compared with the case of undyed cellulose. Although the apparent substantivity of $\mathrm{Cl}$ Direct Blue 1 decreased with an increase in the amount of fixed dye, this dye showed the same saturation value on reactively-dyed cellulose as that on original cellulose. $\mathrm{Cl}$ Reactive Red 120 and Yellow had no different influence on the adsorption of $\mathrm{Cl}$ Direct Blue 1 on cellulose reactively-dyed with them, in spite of the number of sulfonate groups. With increase in the $\mathrm{pH}$ of the dye-bath, the hydroxyl groups of cellulose and dyes dissociated and led tothe reduction of reactive dyes adsorption. A decrease due to the dissociation of cellulose occured at $\mathrm{pH}>10.5$.

The $\mathrm{pH}$-dependence of three vinylsulfonyl reactive dye solutions, C.I. Reactive Red 22, Black 5, and Blue- 
- $\mathrm{Cu}$, on decolorization by cellulose immersed in an aqueous solution was examined under anaerobic and aerobic conditions by Okada et al. [101]. The results showed that with an increase in $\mathrm{pH}$ in the acid region, the rates of decolorization for Red 22 and Black 5 under anaerobic conditions and oxidative decolorization for Blue-Cu under aerobic ones decreased, whereas those of oxidative decolorization for Red 22 increased under aerobic conditions. The rates of decolorization for the three dyes under anaerobic conditions in the alkaline region showed little $\mathrm{pH}$-dependence. The rates of oxidative decolorization under aerobic conditions increased with increasing $\mathrm{pH}$ in the alkaline region.

Cellulose gels regenerated from aqueous alkaliurea solvent for adsorption of Congo Red were investigated by Isobe et al. [102]. In spite of the apparent similarity in pore structures, adsorption of Congo Red by cellulose gels showed striking difference depending on the coagulant types. The adsorption level was significantly higher for organic solvents than for aqueous solutions used as coagulant. The order was: $\mathrm{MeOH}>$ $>\mathrm{EtOH}>$ acetone $>\mathrm{Na}_{2} \mathrm{SO}_{4} \geq \mathrm{H}_{2} \mathrm{SO}_{4}$. The authors suggested that the difference in affinity with Congo Red was due to diffrent polarity of the coagulant. The maximum adsorption capacity was $180 \mathrm{mg} \mathrm{g}^{-1}$ for $\mathrm{MeOH}$-regenerated cellulose.

A novel hybrid hydrogel of IPN was synthesized by the graft copolymerization reaction among cellulose (Cell), polymethacrylic acid (PMAA) and bentonite (Bent), in the presence of MBA as a crosslinker and potassium peroxydisulphate $\left(\mathrm{K}_{2} \mathrm{~S}_{2} \mathrm{O}_{8}\right)$ as an initiator by Anirudhan et al. [103]. The resulting IPN was used as an adsorbent for studying the effectiveness in the removal of methylene blue. The adsorption loading reached the maximum at $\mathrm{pH} 6.5$ with maximum monolayer capacity of $317.7 \mathrm{mg} \mathrm{g}^{-1}$. Batch recycling of PMAA-g-Cell/Bent was conducted and the results confirmed that the sorption capacity of the IPNs was unaffected by the regeneration process.

In order to enhance the sorption capacity of anionic dyes Acid Green, Ismative Violet 2R and Direct Pink 3B, Taleb et al. investigated copolymer hydrogels composed of poly(vinyl alcohol) (PVA) and carboxymethyl cellulose (CMC) prepared by using electron beam irradiation as crosslinking agent [104]. Results showed that the sorption capacity of dyes onto PVA/CMC hydrogel decreased significantly with increase of $\mathrm{pH}$. At lower $\mathrm{pH}$ values (below the $\mathrm{pK}$ of carboxylic groups, approximately 4.6), the -COO-groups in CMC are protonated to $-\mathrm{COOH}$ groups and the negatively charged molecules of dyes cause the increase in dye adsorption. As the $\mathrm{pH}$ increased, the sorbent surface became negatively charged which didn't favor the adsorption of anionic dye molecules due to the electrostatic repulsion between the negatively charged surface and the dye anions. The adsorption capacities varied as direct pink $3 \mathrm{~B}>$ acid green $\mathrm{B}>$ ismative $2 \mathrm{R}$ and the maximum sorption capacity was $140 \mathrm{mg} \mathrm{g}^{-1}$.

\section{Chitosan}

Chitosan is the $\mathrm{N}$-deacetylated derivative of chitin, which is a naturally abundant polysaccharide and the supporting material of crustaceans, insects, etc. and is easily obtained from crustacean shells (such as prawns and crabs), insects and fungi. Chitosan could be produced by alkaline deacetylation of chitin.

The molecular structure of chitosan comprises of $\beta$ (1-4) linked D-glucosamine residues with a variable number of randomly located $\mathrm{N}$-acetyl-glucosamine groups. In spite of the presence of acetamide groups at the C2-positions, chitosan is structurally very similar to cellulose. Celulose has hydroxyl groups at C2-positions in place of acetomaide groups (Figure 9).
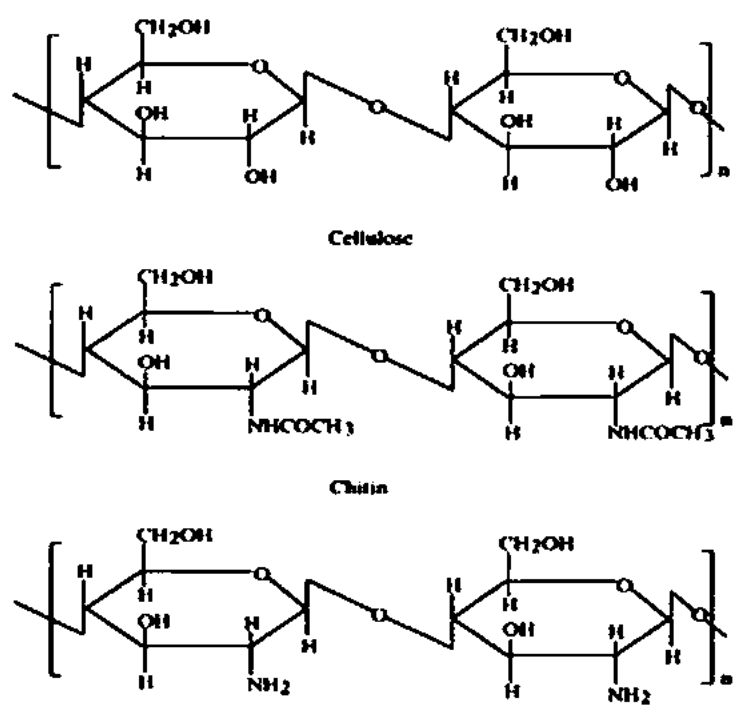

Figure 9. Structure of chitin and chitosan.

Chitosan has a wide range of applications that depend on its physical, chemical, and biological properties. The principal areas are agriculture, wastewater treatment, food and beverages, cosmetics and toiletries, biomedics and pharmaceutics, fibers and textiles and paper technology [106].

Chitosan has excellent properties for the adsorption of heavy metals and dyes, principally due to high hydrophillicity, presence of amine and hydroxyl groups which can serve as active sites and flexible structure of the polymeric chains. However, chitosan is easy to dissolve at low $\mathrm{pH}$, resulting in the limitation of its applications. On the other side, chitosan has very poor sorption capability in alkaline solution. Another problem with chitosan is its poor physicochemical characteristics, in particular porosity, as with most of the other polysaccharides as well. Beside nonporosity, 
chitosan possesses very low specific area ranging between 2 and $30 \mathrm{~m}^{2} \mathrm{~g}^{-1}$, so there is a need to modify natural chitosan physically or chemically in order to improve sorption capability.

The adsorption capacity of chitosan depends on physical parameters such as: crystallinty, porosity and particle size. Generally, with increase of porosity and decrease of particle size and crystallinity, the adsorption capacity increases. Trung et al. determined that decrystallized chitosan could be better than crystalline chitosan for adsorption of azo dyes [107]. The gel formation procedure, freeze drying procedure and crosslinking can decrease the crystallinity and enhance porosity. The main chemical parameters that affect the adsorption capacity are molecular weight, degree of deacetylation, solubility and ionic strength. When comparing the chitosan samples with different degree of deacetylation, adsorption capacity of azo dye increases with increase of degree of deacetylation, as reported by Sasha et al. [108].

Chitosan can be modeled in several shapes: gels, flakes, powders, beads, membranes and particles [109]. There are only a few articles in the literature related to the flake and powder forms of chitosan because of their low surface activity and porosity. Mahmoodi et al. investigated the removal of Direct Red 23 (DR23) and Acid Green 25 (AG25) by raw chitosan from textile effluent in single and binary systems was investigated. The maximum adsorption capacity was in single system, 178 and $155 \mathrm{mg} \mathrm{g}^{-1}$ for removal the AG25 and DR23, respectively. Iqbal et al. used chitosan flakes, extracted from prawns and labeo rohita scales to remove acid yellow dye from water [110]. Prawn scales showed greater adsorption capacity than the labeo rohita scales and reached its maximum at $0.168 \mathrm{mg} \mathrm{g}^{-1}$.

The most widely investigated types of chitosan as adsorbents are beads and gels. Chitosan beads can be formed by precipitation in alkaline solution, or in alkaline bath containing usually glutaraldehyde (GLA), tripolyphosphate (TPP) or epichlorhydrin (EPI) as crosslinker. Crosslinked chitosan have been studied recently to improve its chemical stability in any acidic media. The adsorption capacity depends on degree of crosslinking. In general way, the adsorption capacity can increase or decrease with the extent of cross-linking depending on the functional groups. Chitosan can form crosslinked networks by reaction between the amino or hydroxyl group of the chains with crosslinking agents.

Concerning the specific azo dyes, Chatterjee et al. investigated the chitosan beads for removal of the Congo Red dye [111]. The maximum adsorption capacity was $93 \mathrm{mg} \mathrm{g}^{-1}$ at $\mathrm{pH}$ 6. The presence of sodium chloride at the concentration of 0.5 and $1 \mathrm{M}$ in dye solution reduced the adsorption by 14.4 and $28.0 \%$, respectively. Sodium dodecyl sulphate also inhibited adsorption of Congo red. The ability of chitosan beads, derived from deacetylated crab shell chitin, to remove acid dyes - Acid Green 25 (AG25), Acid Orange 10 (AO10), Acid Orange 12 (AO12), Acid Red 18 (AR18) and Acid Red 73 (AR73) from effluent solution by adsorption has been studied [112]. Based on the Langmuir isotherm analysis, the extremely high monolayer adsorption capacities were determined to be 645,923 , 973, 693.2 and $728 \mathrm{mg} \mathrm{g}^{-1}$ chitosan for AG25, AO10, A012, AR18 and AR73, respectively. The differences in capacities may be due to the difference in the molecular size of dye molecules and the number of sulphonate groups of each dye. The results demonstrated that monovalent and smaller dye particle have superior capacities due to increase in dye/chitosan ratio in the system, enabling deeper penetration of dye molecules to the internal pore structure of chitosan.

The chitosan beads crosslinked by TPP and GLA were used as barriers to the transport of Reactive Black 5 dye in soil column experiments by Lazaridis et al. [113]. The solution of chitosan was added dropwise from a pipette into an aqueous solution of glutaraldehyde $5 \mathrm{~g} / \mathrm{L}$, which also contained $5 \mathrm{~g}$ tripoly phosphate at $\mathrm{pH} 6$, adjusted with an aqueous $\mathrm{HCl}$ solution, so the beads were prepared. The maximum adsorption capacity of Reactive Black 5 by TPP crosslinked chitosan beads was $238 \mathrm{mg} \mathrm{g}^{-1}$. The sorption capacity of Methylene Orange by GLA crosslinked chitosan particles was $140 \mathrm{mg} \mathrm{g}^{-1}$ according Morais et al. [114]. Chen et al. also investigated the adsorption of Reactive Black 5 dye onto GLA crosslinked chitosan beads [115]. The crosslinked chitosan microparticles were prepared through homogeneous coupling reaction and microparticle formation using a sodium hydroxide solution. The maximum adsorption capacity according to Chen et al. was $1680 \mathrm{mg} \mathrm{g}^{-1}$. The significantly higher adsorption capacity obtained by Chen et al. indicated that the sorption depends on the procedure for the preparation of the crosslinked beads [116]. Chitosan beads crosslinked with EPI showed the maximum Red dye adsorption capacity of $52.7 \mathrm{mg} \mathrm{g}^{-1}$. The adsorption of dye decreased in the presence of surfactant dodecylbenzenesulfonate as a result of competitive adsorption for the same sites between the same charged dye and surfactant molecules. The adsorption properties of non-crosslinked and crosslinked chitosan beads with ethylene glycol diglycidyl ether (EGDE) for removal of Acid Red 37 (AC 37) and Acid Blue 25 (AB 25) were compared [117]. It was shown that the adsorption capacities of chitosan for both acid dyes were comparatively higher than those of chitosan-EGDE. The authors explained that the adsorption capacity was lower for crosslinked chitosan beads because of decreasing of the number of free amine groups after crosslinking with EGDE. Adsorption capacities of $A B 25$ were higher then of $A C 37$ for both 
cases, non-crosslinked and crosslinked chitosan beads. The maximum adsorption capacities were followed: $128 \mathrm{mg} \mathrm{g}^{-1}$ for adsorption of AC 37 onto chitosan beads, $59.5 \mathrm{mg} \mathrm{g}^{-1}$ for adsorption the same dye onto chitosan corsslinked with EGDE, $263 \mathrm{mg} \mathrm{g}^{-1}$ for adsorption of $A B 25$ onto chitosan beads and $142.8 \mathrm{mg} \mathrm{g}^{-1}$ for adsorption $A B 25$ onto chitosan crosslinked with EGDE.

Improving chitosan properties such as increasing chelating or complexation properties was attempted by graft copolymerization. Chitosan has two types of reactive groups that can be grafted: a) free amino groups on deacetylated units and b) the hydroxyl groups on the C3 and C6 carbons on acetylated or deacetylated units. The new functional groups incorporated as grafts on chitosan may increase the density of sorption sites, change the $\mathrm{pH}$ range for dye sorption and increase sorption selectivity for the target dye.

Poly(methyl methacrylate) grafted chitosan (Ch-g-PMMA) was used for removal of anionic dyes Procion Yellow MX 8G (PY) and Remazol Brilliant Violet 5R (RV $5 R)$ by Singh et al. [118]. Degree of grafting had big influence on adsorption capacity and with increase in degree of grafting (\%) from 50 to 250 , there was an increase in the adsorption for all dyes. It was observed that percentage removal of dye by Ch-g-PMMA was almost constant for a wide $\mathrm{pH}$ range. According to the Langmuir isotherms, the maximum adsorption capacities of dyes onto Ch-g-PMMA were as for PY and RV 5R 250 and $357 \mathrm{mg} \mathrm{g}^{-1}$, respectively. The same authors investigated removal of the same dyes by chitosan grafted with poly(acrylamide) [119]. The maximum adsorption capacities were significantly higher than capacities obtained by chitosan grafted with PMMA, and reached its maximum 1000 and $1428.6 \mathrm{mg} \mathrm{g}^{-1}$ for PY and RV 5R dye, respectively. Chitosan was also grafted with other methacrylates. Konaganti et al. investigated chitosan grafted with different poly(alkyl methacrylate)s: chitosan grafted poly(methyl methacrylate) (Ch-g-PMMA), chitosan grafted poly(ethyl methacrylate) (Ch-g-PEMA), chitosan grafted poly(butyl methacrylate) (Ch-g-PBMA) and chitosan grafted poly(hexyl methacrylate) (Ch-g-PHMA), for removal of anionic dye Orange $G$ [120]. Also, adsorption capacity of anionic sulfonated dyes -Orange G (Acid Orange 10AO10) and Congo Redonto (CR) Ch-g-PBMA were investigated. The grafted chitosan possessed higher adsorption capacities compared to the values of ungrafted chitosan. Also, the adsorption capacities in all cases increased with increasing the percentage of grafting. The adsorption capacity of these dyes on Ch-g-PBMA followed the order $C R>A O 10$. The adsorption capacity follows the order: Ch-g-PMMA $>$ Ch-g-PEMA $>$ Ch-g-PBMA $>$ Ch-g-PHMA > chitosan, with the adsorption equilibrium capacity of Ch-g-PMMA being 4.5 times that of chitosan.
It could be concluded that some of proposed adsorbents have shown limited ability as raw natural materials to remove the employed dye, while the derivatives of natural polymers could be effectively used in place of commercial adsorbents due to biodegradabillity, easier regenaration, high eficiency and low cost.

\section{CONCLUSIONS}

Intensive industrial development is accompanied by an increasing volume of wastewater, which in terms of environmental protection and sustainable development requires the need to enhance the existing and introduce new processes for wastewater treatment. Azo dyes, which are toxic and naturally very difficult to degrade, require special scientific and technological attention. Considerable efforts are now being made in the research and development of polymeric materials and derivatives as basic materials for new applications because of increasing cost of conventional adsorbents. This review has attempted to cover a wide range of polymeric adsorbents so that the reader can get an idea about the various types and forms of polymeric materials used for the removal of azo dyes from the wastewater. Polymeric adsorbents show increasing advantages over conventional adsorbents because of their simple processing, relatively easy regeneration and the possibility to shape them into most suitable form. The literature reveals that in some cases the modification of the adsorbent increased the removal efficiency. Many of the reported materials can be regenerated conveniently, which can further reduce the cost of the water treatment process.

\section{Acknowledgement}

The authors acknowledge funding from the Ministry of Education, Science and Technological Development of the Republic of Serbia, Projects No. 43009 and 172062.

\section{REFERENCES}

[1] K. Kadirvelu, M. Kavipriya, C. Karthika, M. Radhika, N. Vennilamani, S. Pattabhi, Utilization of various agricultural wastes for activated carbon preparation and application for the removal of dyes and metal ions from aqueous solutions, Biores. Technol. 87 (2003) 129-132.

[2] A.R. Dinçer, Y. Günes, N. Karakaya, E. Günes, Comparison of activated carbon and bottom ash for removal of reactive dye from aqueous solution, Biores. Technol. 98 (2007) 834-839.

[3] D. Shen, J. Fan, W. Zhou, B. Gao, Q. Yue, Q. Kang, Adsorption kinetics and isotherm of anionic dyes onto organo-bentonite from single and multisolute systems, J. Hazard. Mater. 172 (2009) 99-107.

[4] J.O. Duruibe, M.D.C. Ogwuegbu, J.N. Egwurugwu, Heavy metal pollution and human biotoxic effects, Internat. J. Physi. Sci. 2(5) (2007) 112-118. 
[5] D.K. Mahmoud, M.A.M. Salleh, W.A.W.A. Karim, A. Idris, Z.Z. Abidin, Batch adsorption of basic dye using acid treated kenaf fibre char: Equilibrium, kinetic and thermodynamic studies, Chem. Eng. J. 181-182 (2012) 449$-457$.

[6] L. Fan, C. Luo, X. Li, F. Lu, H. Qiu, M. Sun, Fabrication of novel magnetic chitosan grafted with graphene oxide to enhance adsorption properties for methyl blue, J. Hazard. Mater. 215-216 (2012) 272-279.

[7] M. Asgher, H.N. Bhatti, Evaluation of thermodynamics and effect of chemical treatments on sorption potential of Citrus waste biomass for removal of anionic dyes from aqueous solutions, Ecol. Eng. 38 (2012) 79-85.

[8] K.Z. Elwakeel, Removal of Reactive Black 5 from aqueous solutions using magnetic chitosan resins, J. Hazard. Mater. 167 (2009) 383-392.

[9] E. Forgacs, T. Cserhati, G. Oros, Removal of synthetic dyes from wastewaters: a review, Environ. Int. 30 (2004) 953-971.

[10] C.A.M. Huitle, E. Brillas, Decontamination of wastewaters containing synthetic organic dyes by electrochemical methods: A general review, Appl. Catalysis. 87 (2009) 105-145.

[11] N. Masoudzadeha, F. Zakeria, T. B. Lotfabada, H. Sharafi, F. Masoomi, H. S. Zahiri, G. Ahmadian, K. A. Noghabi, Biosorption of cadmium by Brevundimonas sp. ZF12 strain, a novel biosorbent isolated from hot-spring waters in high background radiation areas, J. Hazard. Mater. 197 (2011) 190-198.

[12] T. Robinson, G. McMullan, R. Marchant, P. Nigam, Remediation of dyes in textile effluent: a critical review on current treatment technologies with a proposed alternative, Biores. Technol. 77 (2001) 247-255.

[13] V. Venugopal, K. Mohanty, Biosorptive uptake of $\mathrm{Cr}(\mathrm{VI})$ from aqueous solutions by Parthenium hysterophorus weed: Equilibrium, kinetics and thermodynamic Studies, Chem. Eng. J. 174 (2011) 151-158.

[14] Z.B. Wu, W.M. Ni, B.H. Guan, Application of chitosan as flocculant for coprecipitation of $\mathrm{Mn}$ (II) and suspended solids from dual-alkali FGD regenerating process, J. Hazard. Mater. 152 (2008) 757-764.

[15] M.F. Chong, K.P. Lee, H.J. Chieng, I. Ramli, Removal of boron from ceramic industry wastewater by adsorptionflocculation mechanism using palm oil mill boiler (POMB) bottom ash and polymer, Water Res. 43 (2009) 3326-3334.

[16] S. Song, A. Lopez-Valdivieso, D.J. Hernandez-Campos, C. Peng, M.G. Monroy-Fernandez, I. Razo-Soto, Arsenic removal from high-arsenic water by enhanced coagulation with ferric ions and coarse calcite, Water Res. $\mathbf{4 0}$ (2006) 364-372.

[17] H. Dong, X. Guan, D. Wang, C. Li, X. Yang, X. Dou, A novel application of $\mathrm{H} 2 \mathrm{O} 2-\mathrm{Fe}(\mathrm{II})$ process for arsenate removal from synthetic acid mine drainage (AMD) water, Chemosphere 85 (2011) 1115-1121.

[18] S.G. Segura, E. Brillas, Mineralization of the recalcitrant oxalic and oxamic acids by electrochemical advanced oxidation processes using a boron-doped diamond anode, Water Res. 45 (2011) 2975-2984.
[19] X. Zhao, B. Zhang, H. Liu, J. Qu, Removal of Arsenite by Simultaneous Electro-Oxidation and Electro-Coagulation Process," J. Hazard. Mater. 184 (2010) 472-476.

[20] S.A. Kosa, G. A. Zhrani, M. A. Salam, Removal of heavy metals from aqueous solutions by multi-walled carbon nanotubes modified with 8-hydroxyquinoline, Chem. Eng. J. 181-182 (2012) 159-168.

[21] E. Dana, A. Sayari, Adsorption of heavy metals on amine-functionalized SBA-15 prepared by co-condensation: Applications to real water samples, Desalination 285 (2012) 62-67.

[22] A. Bée, D. Talbot, S. Abramson, V. Dupuis, Magnetic alginate beads for $\mathrm{Pb}$ (II) ions removal from wastewater, J. Colloid. Interf. Sci. 362 (2011) 486-492.

[23] H. Tang, C. Chang, L. Zhang, Efficient adsorption of $\mathrm{Hg}$ (II) ion on chitin/cellulose composite membranes prepared via environmentally friendly pathway, Chem. Eng. J. 173 (2011) 689-697.

[24] K. Xie, W. Zhao, X. He, Adsorption properties of nanocellulose hybrid containing polyhedral oligomeric silsesquioxane and removal of reactive dyes from aqueous solution, Carbohydr. Polym. 83 (2011) 1516-1520.

[25] N. Amin, Removal of direct blue-106 dye from aqueous solution using new activated carbons developed from pomegranate peel: Adsorption equilibrium and kinetics, J. Hazard. Mater. 165 (2009) 52-62.

[26] V.Gómez, M. Larrechi, M. Callao, Kinetic and adsorption study of acid dye removal using activated carbon, Chemosphere 69 (2007) 1151-1158.

[27] R. Tovar-Gómez, D. Rivera-Ramírez, V. Hernández-Montoya, A. Bonilla-Petriciolet, C. Durán-Valle, M. MontesMorán, Synergic adsorption in the simultaneous removal of acid blue 25 and heavy metals from water using a $\mathrm{Ca}(\mathrm{PO})$ 2-modified carbon, J. Hazard. Mater. 199-200 (2012) 290-300.

[28] A. Nesic, S. Velickovic, D. Antonovic, Characterization of chitosan/montmorillonite membranes as adsorbents for Bezactiv Orange V-3R dye, J. Hazard. Mater. 209-210 (2012) 256-263.

[29] S. Dawood,T. Kanti Sen, Removal of anionic dye Congo red from aqueous solution by raw pine and acid-treated pine cone powder as adsorbent: Equilibrium, thermodynamic, kinetics, mechanism and process design, Water Res. 46 (2012) 1933-1946.

[30] S.Deng,Y. Peng Ting, Polyethylenimine-modified fungal biomass as a high-capacity biosorbent for $\mathrm{Cr}(\mathrm{VI})$ anions: Sorption capacity and uptake mechanisms, Environ. Sci. Technol. 39 (2005) 8490-8496.

[31] V.V. Panic, Z.P. Madzarevic, T. Volkov-Husovic, S.J. Velickovic, Poly(methacrylic acid) Based Hydrogels as Sorbents for Removal of Cationic Dye Basic Yellow 28: Kinetics, Equilibrium Study and Image Analysis, Chem. Eng. J. 217 (2013) 192-204.

[32] M. Min, L. Shen, G. Hong, M. Zhu, Y. Zhang, X. Wang, Y. Chen, B. Hsiao, Micro-nano structure poly(ether sulfones)/poly(ethyleneimine) nanofibrous affinity membranes for adsorption of anionic dyes and heavy metal ions in aqueous solution, Chem. Eng. J. 197 (2012) 88-100. 
[33] B.C. Pan, J.L. Chen, Q.X. Zhang, Y.Wang, Treatment and resource reuse of industrial wastewater from production process of phenyl acetic acid, Chin. J. React. Polym. 8 (1999) 82-89.

[34] B.J. Pan, B.C. Pan, W.M. Zhang, Q.R. Zhang, Q.X. Zhang, S.R. Zheng, Adsorptive removal of phenol fromaqueous phase by using a porous acrylic ester polymer, J. Hazard. Mater. 157 (2008) 293-299.

[35] W.G. Feng, Q.X. Zhang, J.L. Chen, Z.Y. Xu, B.C. Pan, X. Su, Treatment of wastewater From production process of 2,3-acid, Chin. J. React. Polym. 8 (1999) 68-75.

[36] L. Lv, B.C. Pan, W.M. Zhang, J.L. Chen, Q.X. Zhang, Study on the treatment of industrial wastewater containing triethylamine with polymeric adsorbents, Chin. J. React. Polym. 9 (2000) 174-180.

[37] B. Pan, B.Pan,W. Zhang, L. Lv, Q. Zhang, S. Zheng, Development of polymeric and polymer-based hybrid adsorbents for pollutants removal from waters. Chem. Eng. J. 151 (2009) 19-29.

[38] F. An, X. Feng, B. Gao, Adsorption property and mechanism of composite adsorbent PMAA/SiO2 for aniline, J. Hazard. Mater. 178 (2010) 499-504.

[39] D. Maksin, A. Nastasović, A. Milutinović-Nikolić, Lj. Suručić, Z. Sandić, R. Hercigonja, A. Onjia, Equilibrium and kinetics study on hexavalent chromium adsorption onto diethylene triamine grafted glycidyl methacrylate based copolymers, J. Hazard. Mater. 209-210 (2012) 99-110.

[40] G. Azhgozhinova, O. Güven, N. Pekel, A. Dubolazov, G. Mun, Z. Nurkeeva, Complex formation of linear poly(methacrylic acid) with uranyl ions in aqueoussolutions, J. Colloid. Interface. Sci. 278 (2004) 155-159.

[41] O. Azzaroni, Polymer brushes here, there, and everywhere: Recent advances in their practical applications and emerging opportunities in multiple research fields. J. Polym. Sci. A Polym. Chem. 50 (2012) 3225-3258.

[42] A. Nastasović, S. Jovanović, D. DJordević, A. Onjia, D. Jakovljević, T. Novaković, Metal sorption on macroporous poly(GMA-Co-EGDMA) modified with ethylene diamine, React. Funct. Polym. 58 (2004) 139-147.

[43] B.F. Senkal, F. Bildik, E. Yavuz, A. Sarac, Preparation of poly(glycidyl methacrylate) grafted sulfonamide based polystyrene resin with tertiary amine for the removal of dye from water, React. Funct. Polym. 67 (2007) 1471$-1477$.

[44] M. Min, L.Shen, G. Hong, M. Zhu, Y. Zhang, X. Wang, Y. Chen, B. S. Hsiao, Micro-nano structure poly(ether sulfones)/poly(ethyleneimine) nanofibrous affinity membranes for adsorption of anionic dyes and heavy metal ions in aqueous solution, Chem. Eng. J. 197 (2012) 88-100.

[45] S.R. Sandeman, V.M. Gunko, O.M. Bakalinska, C.A. Howell, Y. Zheng, M.T. Kartel, G.J. Phillips, S.V. Mikhalovsky, Adsorption of anionic and cationic dyes by activated carbons, PVA hydrogels, and PVA/AC composite, J. Colloid Interface Sci. 358 (2011) 582-592.

[46] N.M. Mahmoodi, F. Najafi, A.Neshat, Poly(amidoamineco-acrylic acid) copolymer: Synthesis, characterization and dye removal ability, Ind. Crops. Prod. 42 (2013) 119-125.

[47] U. Riaz, S.M. Ashraf, Semi-conducting poly(1-naphthylamine) nanotubes: $\mathrm{A} \mathrm{pH}$ independent adsorbent of sulphonate dyes, Chem. Eng. J. 174 (2011) 546-555.

[48] H.K. Can, B. Kirci, S. Kavlak, A.Güner, Removal of some textile dyes from aqueous solutions by poly $(N$-vinyl-2pyrrolidone) and poly( $N$-vinyl-2-pyrrolidone)/K2S2O8 hydrogels, Radiat. Phys. Chem. 68 (2003) 811-818.

[49] C. Valderrama, J.L. Cortina, A. Farran, X. Gamisans, F.X. de las Heras, Kinetic study of acid red "dye" removal by activated carbon and hyper-cross-linked polymeric sorbents Macronet Hypersol MN200 and MN300, React. Funct. Polym. 68 (2008) 718-731.

[50] V. Bekiari, M. Sotiropoulou, G. Bokias, P. Lianos, Use of poly(N,N-dimethylacrylamide-co-sodium acrylate) hydrogel to extract cationic dyes and metals from water, Colloids Surfaces, A 312 (2008) 214-218.

[51] S.E. Abd El-Aal, E.-S.A. Hegazy, M.F. AbuTaleb, A.M. Dessouki, Radiation synthesis of copolymers for adsorption of dyes from their industrial wastes. J. Appl. Polym. Sci. 96 (2005) 753-763.

[52] S. Duran, D. Şolpan, O. Güven, Synthesis and characterization of acrylamide-acrylic acid hydrogels and adsorption of some textile dyes, Nucl. Instrum. Methods Phys. Res., B 151 (1999) 196-199.

[53] Ö.B. Üzüm, E. Karadağ, Equilibrium swelling studies and dye sorption characterization of AAm/SA hydrogels cross-linked by PEGDMA and semi-IPNs with PEG, Adv. Polym. Technol. 31 (2012) 141-153.

[54] Ö.B. Üzüm, E. Karadağ, Water and dye sorption studies of novel semi IPNs: Acrylamide/4-styrenesulfonic acid sodium salt/peg hydrogels. Polym Eng Sci. (2012), doi: 10.1002/pen.23378

[55] Ö.B. Üzüm, E. Karadağ, Behavior of semi IPN hydrogels composed of PEG and AAm/SMA copolymers in swelling and uptake of Janus Green B from aqueous solutions, J. Appl. Polym. Sci. 125 (2012) 3318-3328.

[56] D. Parasuraman, A.K. Sarker, M.J. Serpe, Poly(N-Isopropylacrylamide)-based microgels and their assemblies for organic-molecule removal from water, Chem. Phys. Chem. 13 (2012) 2507-2515.

[57] N. Peppas, P. Bures, W. Leobandung, H. Ichikawa, Hydrogels in pharmaceutical formulations, Eur. J. Pharm. Biopharm. 50 (2000) 27-46.

[58] E. Karadag, D.Saraydin, O.Güven, Interaction of some cationic dyes with acrylamide/itaconic acid hydrogels. J. Appl. Polym. Sci. 61 (1996) 2367-2372.

[59] B. Pan, B. Pan, W. Zhang, L. Lv, Q. Zhang, S. Zheng, Development of polymeric and polymer-based hybrid adsorbents for pollutants removal from waters, Chem. Eng. J. 151 (2009) 19-29.

[60] K. Zheng, B.C. Pan, Q.J. Zhang, W.M. Zhang, B.J. Pan, Y.H. Han, Q.R. Zhang, W. Du, Z.W. Xu, Q.X. Zhang, Enhanced adsorption of $p$-nitroaniline from water by a carboxylated polymeric adsorbent, Sep. Purif. Technol. 57 (2007) 250-256. 
[61] Q.H. Hu, S.Z. Qiao, F. Haghseresht, M.A. Wilson, G.Q.Lu, Adadsorption study for removal of basic red dye using bentonite, Ind. Eng. Chem. Res. 45 (2006) 733-738.

[62] D.Sun, X. Zhang, Y. Wu, X. Liu, Adsorption of anionic dyes from aqueous solution on fly ash. J. Hazard. Mater. 181 (2010) 335-342.

[63] L. Sair, W.R. Fetzer, Water sorption by starches, Ind. Eng. Chem. 36 (1944) 205-208.

[64] V. Rebar, E.R. Fischbach, D. Apostolopoulos, J.L. Kokini, Thermodynamics of water and ethanol adsorption on four starches as model biomass separation systems, Biotechnol. Bioeng. 26 (1984) 513-517.

[65] A.S. Kulik, J.R. Chris de Costa, J. Haverkamp, Water organization and molecular mobility in maize starch investigated by two-dimensional solid-state NMR, J. Agric. Food Chem. 42 (1994) 2803-2807.

[66] C. van den Berg, F.S. Kaper, J.A.G. Weldring, I. Wolters, Water binding by potato starch, J. Food Technol. 10 (1975) 589-602.

[67] D.K. Kweon, J.K. Choi, E.K. Kim, S.T. Lim, Adsorption of divalent metal ions by succinylated and oxidized corn starches, Carbohydr. Polym. 46 (2001) 171-177.

[68] W.C. Chan, T.P. Fu, Mechanism of removing chlorophenolic compounds from solution by a water-insoluble cationic starch, J. Polym. Res. 1 (1997) 47-55.

[69] W.C. Chan, J.Y. Wu, Dynamic adsorption behaviors between $\mathrm{Cu}^{2+}$ ion and water-insoluble amphoteric starch in aqueous solutions, J. Appl. Polym. Sci. 81 (2001) 2849-2855.

[70] W.C. Chan, J.C. Ferng, Mass transport process for the adsorption of $\mathrm{Cr}(\mathrm{VI})$ onto water-insoluble cationic starch synthetic polymers in aqueous systems, J. Appl. Polym. Sci. 71 (1999) 2409-2418.

[71] M.I. Khalil, A.A. Aly, Use of Cationic Starch Derivatives for the Removal of Anionic Dyes from Textile Effluents, J. Appl. Polym. Sci. 93 (2004) 227-234.

[72] B.Z. Ju, Preparation and application of cationic starch with high degree of substitution, PhD Thesis, 2000, pp. 105-126.

[73] F. Renault, N. Morin-Crini, F.Gimbert, P.M. Badot, G. Crini, Cationized starch-based material as a new ionexchanger adsorbent for the removal of C.I. Acid Blue 25 from aqueous solutions, Biores. Technol. 99 (2008) 7573-7586.

[74] R. Klimaviciute, A. Riauka, A. Zemaitaitis, The binding of anionic dyes by cross-linked cationic starches, J. Polym. Res. 14 (2007) 67-73.

[75] S. Xu, J. Wang, R. Wu, J. Wang , H. Li, Adsorption behaviors of acid and basic dyes on crosslinked amphoteric starch, Chem. Eng. J. 117 (2006) 161-167.

[76] M. Zhang, B.Z. Ju, S.F. Zhang, W. Ma, J.Z. Yang, Synthesis of cationic hydrolyzed starch with high DS by dry process and use in salt-free dyeing, Carbohydr. Polym. 69 (2007) 123-129.

[77] F. Delvala, G. Crinib, N. Morinc, J. Vebrel, S. Bertini, G. Torri, The sorption of several types of dye on crosslinked polysaccharides derivatives, Dyes Pigments 53 (2002) 79-92.
[78] R. Cheng, Sh. Ou, M. Li , Y. Li , B. Xiang, Ethylenediamine modified starch as biosorbent for acid dyes, J. Hazard. Mater. 172 (2009) 1665-1670.

[79] Z. Wang, B. Xian, R. Cheng, Y. Li, Behaviors and mechanism of acid dyes sorption onto diethylenetriaminemodified native and enzymatic hydrolysis starch, J. Hazard. Mater. 183 (2010) 224-232.

[80] R. Cheng, B. Xiang, Y. Li, M. Zhang, Application of dithiocarbamate-modified starch for dyes removal from aqueous solutions, J. Hazard. Mater. 188 (2011) 254-260 .

[81] S.N. Pawar, K.J. Edgar, A review of chemistry, properties and applications, Biomaterials 33 (2012) 3279-3305.

[82] A. Martinse, A. Skijak-Braek, O. Smidsrod, Alginate as immobilization material: I. Correlation between chemical and physical properties of alginate gel beads, Biotechnol. Bioeng. 33 (1989) 79-89.

[83] E. W.Shin, R.M. Rowell, Cadmium ion sorption onto lignocellulosic biosorbent modified by sulfonation: the origin of sorption capacity improvement, Chemosphere 60 (2005) 1054-1061.

[84] J.A. Ramsay, W.H.W. Mok, Y.S. Luu, M. Savage, Decoloration of textile dyes by alginate-immobilized Trametes versicolor, Chemosphere 61 (2005) 956-964.

[85] N.M. Mahmoodi, Equilibrium, kinetic and thermodynamic of dye removal using alginate from binary system, J. Chem. Eng. Data 56 (2011) 2802-2828.

[86] B. Voncina, Application of cyclodextrins in textile dyeing, Textile dyeing, P. Hauser (Ed.), InTech, 2011, available from: http://www.intechopen.com/books/textile-dyeing/applicationof-cyclodextrins-in-textile-dyeing.

[87] E.Y. Ozmen, M. Sezgin, A. Yilmaz, M. Yilmaz, Synthesis of $\beta$-cyclodextrin and starch based polymers for sorption of azo dyes from aqueous solutions, Biores. Technol. 99 (2008) 526-531.

[88] G. Crini, Studies on adsorption of dyes on beta-cyclodextrin polymer, Biores. Technol. 90 (2003) 193-198.

[89] E.Yilmaza, S. Memonb, M. Yilmaza, Removal of direct azo dyes and aromatic amines from aqueous solutions using two $\beta$-cyclodextrin-based polymers, J. Hazard. Mater. 174 (2010) 592-597.

[90] D. Klemm, H.P. Schmauder, T.Heinze, Cellulose, in: S. De Baets, E.J. Vandamme, A. Steinbuchel, (Eds.), Polysaccharides. II.Polysaccharides from eukaryotes, Vol. 6. Wiley-VCH, Weinheim, pp. 275-320.

[91] C. Aulin, S. Ahola, P. Josefsson, T. Nishino, Y. Hirose, M. Österberg, L. Wagberg, Nanoscale cellulose films with different crystallinities and mesostructures - Their surface properties and interaction with water, Langmuir 25(13) (2009)7675-7685.

[92] G. Siqueira, J. Bras, A. Dufresne, Cellulosic bionanocomposites: A review of preparation, properties and applications, Polymer 2(4) (2010) 728-765.

[93] N. Lavoine, I. Desloges, A. Dufresne, J. Bras, Microfibrillated cellulose - Its barrier properties and applications in cellulosic materials: A review, Carbohydr. Polym. 90 (2012) 735-764.

[94] O. Chambin, D. Champion,, C. Debray, M.H. RochatGonthier,M. Le Meste, Y. Pourcelot, Effects of different 
cellulose derivatives on drug release mechanism studied at a preformulation stage, J. Controll. Rel. 95 (2004) 101-108.

[95] K. Zih-Perényi, A. Lásztity, S. Pusztai, Study of interference of pharmaceuticals with complexing characteristics in solid phase microextraction of lead on chelating celluloses, Microchem. J. 85 (2007) 149-156.

[96] K.P. Gregoire, J.G. Becker, Design and characterization of a microbial fuel cell for the conversion of a lingocellulosic crop residue to electricity, Biores. Technol. 119 (2012) 208-215.

[97] D.W. O'Connell, C. Birkinshaw, T.F. O’Dwyer, Heavy metal adsorbents prepared from the modification of cellulose: A review, Biores. Technol. 99 (2008) 6709-6724.

[98] N. Buvaneswari, C. Kannan, Plant toxic and non-toxic nature of organic dyes through adsorption mechanism on cellulose surface, J. Hazard. Mater. 189 (2011) 294-300 .

[99] J. Siroky, R.S. Blackburn, T. Bechtold, J. Taylor, P. White, Alkali treatment of cellulose II fibres and effect on dye sorption, Carbohydr. Polym. 84 (2011) 299-307.

[100]S.H. Bae, H. Motomura, Z. Morita, Effect of anionic groups in cellulose on the adsorption of reactive dyes on cellulose, Dyes Pigments 34 (1997)37-55.

[101]Y. Okada, M. Sakai, I. Takahashi, Effect of pH on the fading behavior of vinylsulfonyl azo dyes on cellulose in aqueous solutions, Dyes Pigments 24 (1994) 1-10.

[102] N. Isobe, U.J. Kim, S. Kimura, M. Wada, S. Kuga, Internal surface polarity of regenerated cellulose gel depends on the species used as coagulant, J. Colloid Interf. Sci. $\mathbf{3 5 9}$ (2011) 194-201.

[103]T.S. Anirudhan, A.R. Tharun, Preparation and adsorption properties of a novel interpenetrating polymer network (IPN) containing carboxyl groups for basic dye from aqueous media, Chem. Eng. J. 181-182 (2012) 761-769.

[104] M.F. Abou Taleb, H.L. Abd El-Mohdy, H.A. Abd El-Rehim, Radiation preparation of PVA/CMC copolymers and their application in removal of dyes, J. Hazard. Mater. 168 (2009) 68-75.

[105]N. Majeti V.R. Kumar, A review of chitin and chitosan applications, React. Funct. Polym. 46 (2000) 1-27.

[106]M. Rinaudo, Chitin and chitosan: Properties and applications, Prog. Polym. Sci. 31 (2006) 603-632.

[107]T.S. Trung, C.H. Ng, W.F. Stevens, Characterization of decrystallized chitosan and its application in biosorption of textile dyes, Biotechnol. Lett. 25 (2003) 1185-1190.
[108]T.K. Saha, S. Karmaker, H. Ichikawa, Y.J. Fukumori, Mechanisms and kinetics of trisodium 2-hydroxy-1,1'-azonaphthalene-3,4',6-trisulfonate adsorption onto chitosan, J. Colloid Interf. Sci. 286 (2005) 433-439.

[109] N.M. Mahmoodi, R. Salehi, M. Arami, H. Bahrami, Dye removal from colored textile wastewater using chitosan in binary system, Desalination 267 (2011) 64-72.

[110]J. Iqbal , F.H. Wattoo, M.H.S. Wattoo, R. Malik, S.A. Tirmizi, M. Imran, A.B. Ghangro, Adsorption of acid yellow dye on flakes of chitosan prepared from fishery wastes, Arabian J. Chem. 4 (2011) 389-395.

[111]S. Chatterjee, B.P. Chatterjee, A.K. Guha, Adsorptive removal of Congo Red, a carcinogenic textile dye by chitosan hydrobeads: Binding mechanism, equilibrium and kinetics, Colloids Surfaces, A 299 (2007) 146-152.

[112]Y.C. Wong, Y.S. Szeto, W.H. Cheung, G. McKay, Biosorption of acid dyes on chitosan-equilibrium isotherm analyses, Process Biochem. 39 (2004) 693-702.

[113] N.K. Lazaridis, H. Keenan, Chitosan beads as barriers to the transport of azo dye in soil column, J. Hazard. Mater. 173 (2010) 144-150.

[114] W.A. Morais, A.L.P. Fernandes, T.N.C. Dantas, M.R. Pereira, J.L.C. Fonseca, Sorption studies of a model anionic dye on crosslinked chitosan, Colloids Surfaces, A 310 (2007) 20-31.

[115]A.H. Chen, S.M. Chen, Biosorption of azo dyes from aqueous solution by glutaraldehyde-crosslinked chitosans, J. Hazard. Mater. 172 (2009) 1111-1121.

[116]A.R. Cestari, E.F.S. Vieira, J.A. Mota, The removal of the indigo carmine dye from aqueous solutions using crosslinked chitosan-evaluation of adsorption thermodynamics using a full factorial design, J. Hazard. Mater. 160 (2008) 337-343.

[117]A. Kamari, W.S.W. Ngah, L.K. Liew, Chitosan and chemically modified chitosan beads for acid dyes sorption, J. Environment. Sci. 21 (2009) 296-302.

[118]V. Singh, A.K. Sharma, D.N. Tripathi, R. Sanghi, Poly(methylmethacrylate) grafted chitosan: An efficient adsorbent for anionic azo dyes, J. Hazard. Mater. 161 (2009) 955-966.

[119]V. Singh, A.K.Sharma, R.Sanghi, Poly(acrylamide) functionalized chitosan: an efficient adsorbent for azo dyes from aqueous solutions, J. Hazard. Mater. 166 (2009) 327-335.

[120]V.K. Konaganti, R. Kota, S. Patil, G. Madras, Adsorption of anionic dyes on chitosan grafted poly(alkyl methacrylate)s, Chem. Eng. J. 158 (2010) 393-401. 


\section{IZVOD}

\section{ADSORPCIJA AZO BOJA NA POLIMERNIM MATERIJALIMA}

Vesna V. Panić ${ }^{1}$, Sanja I. Šešlija ${ }^{1}$, Aleksandra R. Nešić ${ }^{2}$, Sava J. Veličković $^{3}$

${ }^{1}$ Inovacioni centar, Tehnološko-metalurški fakultet, Univerzitet u Beogradu, 11000 Beograd, Srbija

${ }^{2}$ Institut za Nuklearne nauke Vinča, Univerzitet u Beogradu, 11000, Beograd, Srbija

${ }^{3}$ Tehnološko-metalurški fakultet, Univerzitet u Beogradu, 11000 Beograd, Srbija

(Pregledni rad)

Intenzivan industrijski razvoj praćen je sve većom količinom otpadnih voda, što u smislu zaštite životne sredine i održivog razvoja nalaže potrebu poboljšanja postojećih i uvodjenje novih postupaka obrade otpadnih voda. Posebnu naučnotehnološku pažnju zahtevaju azo boje, koje su veoma toksične i u prirodi veoma teško razgradive. Azo boje su podložne bioakumulaciji, a zbog kancerogenih i mutagenih svojstava neretko su pretnja zdravlju ljudi i očuvanju okoline. Primenu fizičko-hemijskih metoda za uklanjanje azo-boja iz otpadnih voda često ograničavaju visoke cene, potrebe za odlaganjem nastalog štetnog mulja ili nastanak toksičnih sastojaka razgradnje. Adsorpcija je jedna od najzastupljenijih metoda za uklanjanje raznih zagadjivača iz otpadnih voda zbog jednostavnosti, ekonomičnosti i efikasnosti ove metode. S obzirom da su konvencionalni adsorbenti, kao što je aktivni ugalj, veoma skupi, u poslednje vreme se sve više ulaže u ispitivanja $i$ razvoj novih materijala za uklanjanje zagadjivača iz otpadnih voda koji će biti lako razgradivi, netoksični, jeftini i efikasni u njihovom uklanjanju. $U$ ovom radu biće prikazan pregled iz literature polimernih materijala za uklanjanje azo boja iz otpadnih voda. Polimerni materijali pokazuju prednosti u odnosu na konvencionalne adsrobente zbog jednostavne upotrebe i rukovanja s njima i mogućnosti oblikovanja u pogodne i željene forme. Adsorpcija na polimernim materijalima je najčešće reverzibilan proces, što nije slučaj kod konvencionalnih adsorbenta. Adsorbovana boja na polimernim materijalima, u zavisnosti od tipa boje, se lako može desorbovati u kiseloj ili alkalnoj sredini, kao i u acetonu, tako da se materijal može regenerisati i ponovo koristiti za uklanjanje boja iz otpadnih voda. U ovom radu će biti prikazani sintetički i prirodni polimeri u formi hidrogela, umreženih $i$ kalemljenih sistema za uklanjanje azo boja. Takodje, prikazan je efekat različitih parametara kao što su koncentracija, $\mathrm{pH}$ i temperatura rastvora boje, na adsorpciju na polimernim materijalima.
Ključne reči: Adsorpcija • Azo boje • Sintetički polimeri • Hidrogelovi • Prirodni polimeri 